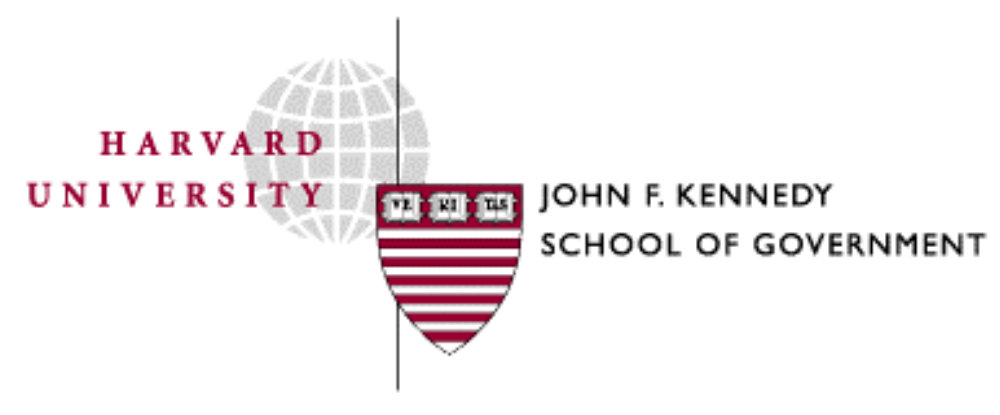

Faculty Research Working Papers Series

\title{
How Did the Social Policy Changes of the 1990s Affect Material Hardship among Single Mothers? Evidence from the CPS Food Security Supplement
}

Scott Winship and Christopher Jencks

June 2004

RWP04-027 belongs to the author(s). Papers may be downloaded for personal use only. 


\title{
How Did the Social Policy Changes of the 1990s Affect Material Hardship among Single Mothers? Evidence from the CPS Food Security Supplement
}

\author{
By \\ Scott Winship \\ Sociology \& Social Policy Program, John F. Kennedy School of Government \\ Harvard University \\ and \\ Christopher Jencks \\ John F. Kennedy School of Government \\ Harvard University
}

Draft of June 16, 2004

We are indebted to Joseph Swingle for tabulations from the March CPS and to Andrew Clarkwest for tabulations from the Decennial Census. Bethney Gundersen, Joe Harkness, Sandra Hofferth, Susan Mayer, Christopher Winship, James Ziliak, and seminar participants at Harvard's Kennedy School of Government all made helpful suggestions but bear no responsibility for any remaining errors. Mark Nord of the US Department of Agriculture provided invaluable advice about the data. The US Department of Agriculture's Economic Research Service provided partial financial support through its Small Grants Program, administered by the Joint Center for Poverty Research at the University of Chicago and Northwestern University. In addition, Winship received support from the National Science Foundation's Graduate Research Fellowship program and an NSF Integrative Graduate Education and Research Traineeship Grant (\#98070661), while Jencks received support from the Center for Advanced Study in the Behavioral Sciences. Please send comments to swinship@wjh.harvard.edu. 


\title{
How Did the Social Policy Changes of the 1990s Affect Material Hardship among Single Mothers? Evidence from the CPS Food Security Supplement \\ By Scott Winship and Christopher Jencks
}

\begin{abstract}
$\underline{\text { Abstract }}$
Although many opponents of welfare reform predicted that it would increase hardship, the official poverty rate for female headed families with children fell from 42 percent in 1996 to 34 percent in 2002. Skeptics have nonetheless argued that declines in official poverty rates may have been accompanied by increases in material hardship, since single mothers who entered the labor market often incurred new expenses and lost valuable noncash benefits. We investigate this possibility using the Current Population Survey's Food Security Supplement. Food-related problems declined among mother-only families between 1995 and 2000 and rose between 2000 and 2002, but the decline was far larger than the subsequent increase. These changes parallel changes in the official poverty rate during the same years. In contrast to previous economic expansions, the proportional decline in poverty during the late-1990s was at least as large among mother-only families as among two-parent families. We argue that this change was linked to welfare reform and other social policy changes that encouraged single mothers to enter the labor force. As a result, single mothers' material standard of living probably improved more during this economic expansion than during earlier ones.
\end{abstract}

KEYWORDS: WELFARE, POVERTY, FOOD SECURITY 


\section{How Did the Social Policy Changes of the 1990s Affect Material Hardship among Single Mothers? Evidence from the CPS Food Security Supplement \\ By Scott Winship and Christopher Jencks}

The most recent wave of welfare reform began in 1992 when the Department of Health and Human Services started approving state "waivers" that gave welfare recipients more incentives to seek work. It accelerated after 1996, when the Personal Responsibility and Work Opportunity Reconciliation Act (PRWORA) gave states unprecedented discretion in setting eligibility standards, established more stringent work requirements for those receiving federally funded benefits, and imposed a five-year lifetime limit on federal benefits for most recipients. During this period Congress also expanded the Earned Income Tax Credit (EITC), strengthened child support enforcement, and made more money available to states for subsidized childcare and health care. These changes in social policy were followed by a dramatic decline in the number of families receiving cash welfare benefits. The ratio of families receiving welfare to families with children under eighteen headed by unmarried women fell from 0.58 in 1992 to 0.22 in 2002 (see Figure 1). This paper tries to determine how all these changes, taken together, affected the material well-being of mother-only families.

\section{Background and Analytic Strategy}

Perhaps the most common approach to evaluating the impact of welfare reform has been to track families that left the welfare rolls and ask them how they are doing. Such studies are valuable, but they have two major limitations. First, response rates are low. Welfare leavers are hard to find, and those who have experienced serious problems are 
likely to be especially hard to find. Second, although the welfare rolls fell after 1993 partly because the exit rate rose, they also fell because the entry rate fell [Blank, 2002]. Because we cannot identify the families that would have joined the rolls if the ground rules had not changed, we cannot determine how reform affected their well-being.

One way to sidestep both of the foregoing problems is to look at changes in the wellbeing of all mother-only families. Perhaps the most obvious approach is to look at changes in the poverty rate among unmarried mothers. ${ }^{1}$ The Census Bureau reports an official poverty rate for all families in which an unmarried woman is the household head and lives with related children under the age of eighteen. Only about 80 percent of single mothers head their own household, but many of the rest live in households headed by an unmarried female relative (usually their mother but sometimes an aunt or sister). As a result, poverty statistics for unmarried female heads with related children covered 88 percent of all single mothers in 1980, 85 percent in 1990, and 89 percent in $2000 .^{2}$ The remaining single mothers lived in households headed by either a married couple (usually their parents) or an unmarried male (usually their boyfriend). Single mothers who live with a married parent are seldom poor. Boyfriends who can afford a place of his own are seldom poor either. Thus while the poverty series for unmarried female heads living with related children under eighteen overestimates the poverty rate for all single mothers, it is probably a good indicator of the overall trend.

Figure 1 shows that while the poverty rate for unmarried female heads with related children under eighteen fell in the early 1960s, it showed no clear trend between the late

\footnotetext{
${ }^{1}$ Here and throughout we use the term "unmarried" to describe both individuals who say they are unmarried and individuals who say that they are married but that their spouse lives elsewhere.

${ }^{2}$ We are grateful to Andrew Clarkwest for these tabulations, which come from decennial censuses.
} 
1960s and the mid-1990s. After 1996 the rate declined dramatically, reaching an all-time low of 33 percent in 2000 before climbing back to 34 percent in $2002{ }^{3}$ Unfortunately, official poverty counts have many well-known problems. Some of these problems imply that the apparent decline in poverty among unmarried female heads could overstate declines in their chances of experiencing material hardship, while some imply the opposite bias.

The official poverty rate for female heads with children could overstate the reduction in material hardship during the late 1990s for three main reasons:

1. The official poverty rate ignores noncash benefits, such as Food Stamps and Medicaid. Unmarried female heads were less likely to get Food Stamps and Medicaid in the late 1990s than in either the 1980s or the early 1990s.

2. Welfare reform increased the proportion of single mothers who worked [Ellwood, 2000; Blank, 2002]. Working usually increases an unmarried mother's income, but in most cases it also increases her expenses, since she is likely to spend more on childcare, transportation, and clothes. Official poverty statistics count only the increase in income, not the increase in expenses.

3. In the early 1990s many AFDC recipients made ends meet by supplementing their welfare checks with unreported earnings from off-the-books jobs and with gifts from family members and boyfriends [Edin and Lein, 1997]. Taking a regular job probably reduced this kind of unreported income. Mothers cannot

\footnotetext{
${ }^{3}$ Reweighting the March, 2000 CPS with population controls derived from the 2000 Census rather than the 1990 Census and expanding the sample by half using the new population controls raised the estimated poverty rate for female households with no husband present and related children under eighteen from 32.5 to 33.0 percent. Because the first estimate uses the same procedures as earlier estimates, we have shown it in Figure 1.
} 
work simultaneously at both an off-the-books job and an on-the-books job, and relatives are less likely to help out financially when a mother is working. The shift from welfare to regular employment is therefore likely to have increased unmarried mothers' true income less than it increased their reported income.

These three factors led Jencks [1997] to predict that while moving single mothers from welfare to low-wage jobs would probably increase their reported income, it might lower their material standard of living. This paper tests that hypothesis.

One reason why this hypothesis might prove false is that the official poverty rate also has problems that could lead it to underestimate the gains made by unmarried female heads in the late 1990s.

1. Official poverty statistics ignore the Earned Income Tax Credit (EITC), which was larger in the late 1990 s than in earlier years. Federal and state childcare benefits also expanded dramatically over the late 1990s.

2. The Census Bureau calculates poverty for families, not households, and it defines a family as including only those household members who are related by blood, marriage, or adoption. Cohabiting couples are not members of the same family even if they are raising children together. CPS data show that 11.7 percent of single mothers who headed their own household reported that at least one unrelated adult lived in their household in 2002 , compared to only 7.4 percent in 1990. ${ }^{4}$ Few unmarried mothers allow their boyfriend to live in their house unless he helps pay the bills, so this change probably meant that material hardship

\footnotetext{
${ }^{4}$ We are indebted to Joseph Swingle for these estimates.
} 
among unmarried female heads fell a little faster than the official poverty rate implies.

3. The Office of Management and Budget updates the poverty line every year using the Consumer Price Index (CPI). The CPI almost certainly overstated inflation in the 1970s and 1980s. As a result, official income statistics understated the increase in living standards during these years [Jencks, Mayer, and Swingle, 2004]. Changes in the way the CPI is calculated have reduced this bias over time, but many economists believe that there is still a significant upward bias in the CPI. If they are right, material hardship should have fallen slightly faster than the official poverty rate in the late 1990s.

Ideally, we would like to use changes in material hardship, broadly defined, as our criterion for assessing the accuracy of estimates based on official poverty statistics. In this paper, however, we focus on only one form of material hardship, namely whether single mothers reported difficulties in feeding their family adequately. ${ }^{5}$ Using this criterion, trends in the official poverty rate appear to be a valid indicator of trends in material hardship between 1995 and 2002.

Confirming that single mothers' material standard of living improved is easier than determining why it improved. The labor market was unusually strong during the 1990s, and this fact alone would surely have benefited some single mothers, even if government policies targeted at low-income families had not changed. We try to distinguish the

\footnotetext{
${ }^{5}$ For a somewhat similar analysis that focuses on food expenditures see Meyer and Sullivan [2004]. Meyer and Sullivan [2003] argue that consumption measures reflect well-being better than income measures do. See also Bhattacharya, Currie, and Haider [2002], who find that dietary inadequacy among preschool children is better predicted by poverty than by food insecurity measures but that both predict dietary inadequacy for adults.
} 
effects of a tighter labor market from the effects of social policy changes by combining two kinds of evidence.

First, we compare trends among mother-only families with trends among two-parent families, who were less affected by welfare reform, expansion of the Earned Income Tax Credit, and expanded childcare subsidies. This comparison suggests that changes among single mothers were slightly more sensitive to the business cycle than changes among married parents. The implications of that fact depends on how earlier expansions affected two-parent and mother-only families. We do not know how previous business cycles affected food-related problems among different kinds of families, but we do have data on how earlier upturns and downturns affected poverty rates. These data suggest that when labor markets tightened during the late 1960s and late 1980s poverty fell more among two-parent families than among mother-only families.

We attribute the fact that poverty dropped slightly faster in proportional terms among single mothers than among married parents during the late 1990s to changes in social policy between 1992 and 1996. By using both carrots and sticks to lure single mothers into the labor market, these policy changes ensured that single mothers gained more from rising demand for unskilled workers than they otherwise would have. Without these policy changes past experience suggests that a tight market would have had a more modest impact on poverty among mother-only families. Whether these policy changes would have yielded the same material benefits for single mothers in a slacker labor market is not yet clear. Both official poverty statistics and data on food-related problems suggest that the recession of 2001-02 had surprisingly modest effects on single mothers, but we do not yet know what happened in 2003. 


\section{Data}

Our data on food-related problems come from the Food Security Supplement (FSS) to the Census Bureau's monthly Current Population Survey. The US Department of Agriculture (USDA) designs the FSS. The Census Bureau has administered it annually since 1995. The FSS asks questions about a wide range of food-related problems, including worries about the household's food supply, perceived dietary inadequacy, reduced food intake, and hunger. It also asks respondents about their strategies for coping with food insufficiency, their levels of food expenditure, and the extent to which they rely on public and private food programs. Between 34,000 and 51,000 households participated in each year for which we have data. ${ }^{6}$

Seasonal variation. Between 1995 and 2001 the FSS was conducted in April of oddnumbered years and in August or September of even-numbered years. In 2001, the Census Bureau conducted a second FSS in December. All subsequent surveys have also taken place in December. The data collected in December 2003 have not yet been released for secondary analysis.

The FSS asks households about their experiences during the twelve months prior to the survey, so our data describe households' experiences between April 1994 and December 2002. ${ }^{7}$ Because all FSS surveys ask about experiences during the previous

\footnotetext{
${ }^{6}$ For most of the surveys, about 80 percent of households eligible for the CPS and about 85 percent of those who participated in the CPS also participated in the FSS (see Appendix Table A.1, lines 4-6). We present descriptive statistics for our samples in Appendix Table A.2. In all analyses, we weight the FSS data to be representative of the civilian non-institutional population of the United States.

${ }^{7}$ All of our trends in food problems are for families. Alternatively, we could have chosen to focus on households. This would make our exposition somewhat easier, since the food security items are measured at the household level. But shifting from families to households as our unit of analysis could obscure changes in food security when households "double up". The number of food-insecure households, for example, might be artificially reduced as a result of two food-insecure households moving in together to form a single household. Improvements among single mothers relative to two-parent couples then would
} 
twelve months, each month should in theory have an equal influence on responses. In theory, therefore, seasonal variation in food-related problems should not influence the frequency with which problems are reported, even when the survey month changes. In reality, however, respondents interviewed August or September consistently report more food-related problems over the previous twelve months than respondents interviewed in April.

USDA has identified three possible reasons for this seasonal pattern, all of which assume that respondents' reports are disproportionately influenced by their recent experience. First, high summer temperatures increase cooling costs, which might cut into food budgets in the months prior to the August and September surveys. Of course, heating costs might have a similar impact on the April estimates. Second, subsidized school meals are not available to most children during the summer, making it more expensive for poor families to feed their children. Mark Nord and his colleagues have provided strong evidence for both of these explanations [Nord, 2003; Nord and Romig, 2003]. A third hypothesis, which is harder to test, is that working parents' childcare expenses rise when school is not in session, leaving less money for food. These explanations for the high level of food problems in late-summer surveys do not appear to imply any systematic difference between April and December. ${ }^{8}$ We cannot rule out the possibility that the FSS overstates or understates the true change in food-related problems

be overstated. Nevertheless, the results of this paper are substantively unchanged when we consider households instead of families.

${ }^{8}$ If prevalence rates are higher in months with high energy costs, December would produce higher prevalence rates than April only if respondents paid their heating bills in advance and concentrated on their experience over the past thirty days rather than, say, the past ninety days. Nationally, the average temperature in April 2001 was 54 degrees Fahrenheit, compared with 37 degrees in December, but the average temperature from February through April is very similar to the average from October through December (figures from http://lwf.ncdc.noaa.gov/oa/climate/research/cag3/NA.html). 
between April and December, but the direction of the bias cannot be predicted from what we currently know, and there is no direct evidence for its existence.

Because of seasonal variation the best way to estimate trends is to combine trend estimates from surveys conducted in the same months but different years. Our bivariate analyses focus on the four April surveys and the two December surveys. Our multivariate models first use the 1995-2000 surveys and a dummy variable distinguishing April surveys from late summer surveys to estimate pre-recession linear trends. We then estimate the changes between April 1999 and April 2001 and between April 1999 and December 2002 from models using dummy variables for each survey.

The food security index. USDA uses eighteen items from the FSS to determine a household's level of "food security." Ten of these "core" items are asked of all households. The other eight core items are asked only if households include children under the age of eighteen. USDA classifies households as "food insecure" if they report three or more of the eighteen core problems. It further classifies households according to the degree of hunger present. Originally, the term food security was meant to be analogous to job security. Just as people feel better when they are not worried about losing their job, so too they feel better when they are not worried about running short of food. But USDA does not actually classify families as "food insecure" simply because they report worrying about not having enough food. Instead, USDA restricts the label "food insecure" to families that report at least one deficiency in what they actually ate. While this labeling scheme is not ideal, we use it when we use USDA's measure.

When we construct our own measures, we describe them as indicators of "foodrelated problems." In addition to the eighteen core items we looked at roughly thirty other FSS measures of food-related problems that USDA does not include in its food 
security index. We highlight ten measures from the full FSS that we believe are representative. $^{9}$

Screening. To reduce respondent burden, the FSS uses screening questions to exclude households that are very unlikely to report food-related problems. These screens inevitably exclude some people who would have reported one or more problems if they had been asked about them. Excluding such individuals would pose no problem for trend analysis if the screens had always been the same, but in fact they changed over time. USDA has developed a series of "common screens" to make the data consistent from year to year, but they may not be perfect. We therefore checked our conclusions against two items that were asked of all respondents prior to the screen. We report trends for one of these items, which asks whether household members had to stretch the household's food supply due to a shortage of cash. ${ }^{10}$

Family income. The CPS collects detailed income data in March, but because of the way respondents rotate in and out of the CPS sample, these data are available for less than half our sample. The analyses reported here therefore rely on a question in each family's first CPS interview that asks respondents to place their family income in one of fourteen categories. Because these categories remain the same from 1995 to 2002, the purchasing power of families in a given category tends to fall. ${ }^{11}$ After experimenting with various transformations of this income measure, we decided to use the inflationadjusted midpoint of each category to predict the number of problems households

\footnotetext{
${ }^{9}$ We chose not to use the FSS's experimental split ballot items in our analysis.

${ }^{10}$ All of our analyses use the common screens for those questions that are asked after a screen is applied in any year as well as for our summary measures. For more information on the screening methodology consult the appendix.

${ }^{11}$ The CPI indicates that the purchasing power of the dollar declined by an average of 2.4 percent per year during this period.
} 
experienced. ${ }^{12}$ We then include this predicted measure in our models to control for changes in inflation-adjusted income.

Family types. Our target population includes all mothers who live with children of their own who are under the age of eighteen. If the mother is both married and living with her husband, we describe her as living in a "two-parent family." Otherwise, we describe her as living in a "mother-only family," even if she is cohabiting with the father of her children. The rationale for treating cohabiting mothers as unmarried is twofold. First, the FSS income question asks about family income, not total household income, so if unmarried mothers defined their "family" the way the Census Bureau does, they would not include the income of a partner to whom they were not married. Second, by the early 1990s cohabiting partners' income was seldom counted when calculating eligibility for welfare benefits or childcare subsidies and was never counted when calculating EITC benefits. Changes in these programs during the 1990s are therefore likely to have

\footnotetext{
${ }^{12}$ Specifically, we assigned each mother the midpoint of her income category (or 1.5 times the category floor for mothers in the top income category) and adjusted these income figures to constant 2001 dollars using the CPI-U-RS, The income measure refers to the income of the household head's family. We then used locally weighted regression to predict the number of core problems $(0-18)$ using the new income measure. Locally weighted regression estimates a separate linear model for each observation, using a subset of points in the neighborhood of an observation and weighting nearby points more heavily than distant ones. We conducted the locally weighted regression separately for single mothers and for married mothers, pooling all nine surveys in both cases. Finally, we used the predicted values as income controls in our models. Our results were similar when we used category dummies to control for income. In any given year, the categorical measure in the FSS data predicts food-related problems better than either a household's continuous March income, equivalent categorical dummies constructed from the March income measure, or various transformations of these measures (using, for instance, the natural log of category midpoints). We also tried including both FSS category dummies and dummies for categories constructed from the March income measure, but again our results were unaffected. The correlation between the two categorical measures ranged from .72 to .77 for mother-only families and from .71 to .76 for two-parent families, depending on the year.
} 
affected cohabiting mothers in the same way as unmarried mothers, not married mothers. ${ }^{13}$

\section{Trends in Food-Related Problems among Mother-Only Families}

Table 1 shows changes in ten measures of food related problems among mother-only families between April 1995 and December 2002. The first measure, which asks whether mothers ran short of money for food or had to stretch food, covers all single mothers. The nine remaining measures assume that mothers who were not identified as being "at risk" in the screening questions did not experience the problem. The first of these nine screened measures shows the mean number of problems from USDA's eighteen-item food security index. The second screened measure shows the percentage of respondents reporting three or more "core" problems. These are the respondents whom USDA counts as "food insecure."

The last seven screened measures are specific questions asked of at-risk households. Some of those items are included in the food security index and some are not. Some of these problems, like worrying about whether food would run out or borrowing foods from others, are quite common. Others problems, like losing weight due to poverty or having a child who went hungry for a whole day, are relatively infrequent.

All ten measures in Table 1 suggest that single mothers had fewer problems in April 2001 than they had had in April 1995. These declines are statistically significant at the

\footnotetext{
${ }^{13}$ If there are multiple mother-only families in a household, as there are when the daughter of a single mother lives at home and is herself a single mother, we include all of these mothers, using the householdlevel FSS variables for each family. We exclude all persons living in group quarters.
} 
0.001 level in all but two cases. The broader set of 28 indicators that we examined also became less frequent, and 21 of the 28 declines were statistically significant. ${ }^{14}$

The biggest declines occurred from 1995 to 1997, when eight out of ten declines were significant at the 0.05 level (and another nearly so). Eight out of ten problems also declined between 1997 and 1999, but only four of these declines were significant at the 0.05 level. Two measures showed small increases between 1997 and 1999, although neither increase was significant at the 0.05 level. Overall, food-related problems clearly declined between April 1995 and April 1999, even though the proportion of single mothers receiving welfare fell from 58 to 29 percent.

Between April 1999 and April 2001, in contrast, half the FSS measures in Table 1 increased while half declined. None of these ten changes is statistically significant at the 0.05 level. The same pattern holds among the twenty other measures of food-related problems that we examined, although a few increases in the problems that adults experienced were at least marginally significant. Neither measures unaffected by the FSS screening, nor our summary measures, nor measures involving child problems show any clear trend between April 1999 and April 2001.

Table 1 also shows the prevalence of food-related problems in the December 2001 and December 2002 FSS. We had expected to find an increase in food-related problems between April and December of 2001, when unemployment began to rise, but Table 1 provides surprisingly weak support for this expectation. Eight of the ten measures in Table 1 suggest that food-related problems increased between April and December of

\footnotetext{
${ }^{14}$ All of the FSS items are measured at the household level. The prevalence rates should therefore be interpreted as the percentage of mother-only families living in households that experienced a problem, not the percentage of mother-only families who experienced a problem. For linguistic simplicity we generally ignore this distinction. See the appendix for information about how we estimated standard errors.
} 
2001, but none of the changes is significant at the 0.05 level. Among the broader set of problems we examined, increases were again more common than decreases, but again none of the changes was significant at the 0.05 level. ${ }^{15}$

The question about borrowing food was dropped in 2002, but seven of nine remaining measures in Table 1 suggest that problems increased between December 2002 and December 2001, although once again none of the changes is statistically significant. Furthermore, fewer respondents said that they had run short of money or stretched food in 2002 than in 2001. In our full set of measures, there were 22 increases and 7 decreases over the course of 2002, but few were statistically significant.

Overall, however, 21 of 29 indicators worsened among mother-only families, and if we compare December 2002 to April 1999, seven of these changes were significant at the 0.05 level. Expressed as monthly changes, these seven increases were 31 to 70 percent of the corresponding monthly decreases in the same measure between April 1995 and April 1999. The net result was that mother-only families reported less hardship in 2002 than in 1995.

Figure 2 shows the proportion of mother-only families reporting three or more problems in each survey between April 1995 and December 2002. These are the families that USDA classifies as "food insecure." The black diamonds show the means for each survey, while the solid line shows the linear trend from April 1995 through August 2000, when the labor market was tightening. ${ }^{16}$ The proportion of mother-only families

\footnotetext{
${ }^{15}$ From April to December of 2001, of 21 indicators that ask whether households experienced a problem in the previous twelve months, 8 showed declines and 13 showed increases. The argument in the text implies that the change in food problems from September 2000 to December 2001 is biased downwards because of seasonal variation. We examined changes between these surveys and found 10 increases in food problems (with three statistically significant at the 0.10 level) and 11 declines (with one significant at the 0.10 level). ${ }^{16}$ The intercept of the trend line includes the fixed effect of the seasonal dummy, set at its mean over the six surveys.
} 
classified as "food insecure" declined by about a sixth between 1995 and 2000. This is consistent with the change in the poverty rate among female heads with children, which fell by about a fifth during this period. Food insecurity rose by one percentage point between April 1999 and December 2002. ${ }^{17}$ This too is consistent with changes in the official poverty rate among female heads with children, which rose by 0.7 points between 2000 and $2002 .^{18}$

Figure 3 shows a more stringent measure of food-related problems, namely the proportion of single mothers reporting eight or more problems. These are mothers whom USDA labels "food insecure with hunger." Changes in this measure provide a check on whether extreme poverty and hardship rose during the economic downturn that began in 2001. Food insecurity with hunger fell by almost a third among mother-only families between 1995 and 2000 (from 11.4 to 7.3 percent). Hunger appears to have become more common between April of 1999 and April of 2001, but once again the increase is not statistically significant. There is very little change in reported hunger after April 2001.

In an effort to pinpoint the sources of these changes, Table 2 presents the results of OLS models estimating monthly changes in four summary measures of food-related problems: the proportions experiencing at least one core problem, at least three core problems, and at least eight core problems, and the average number of core problems experienced. ${ }^{19}$ The "exogenous controls" model includes only the seasonal dummy (for the 1995-2000 period of falling unemployment), dummies for region of the country,

\footnotetext{
${ }^{17}$ Changes in the probability of experiencing at least one problem show the same patterns, as do changes in the mean number of core problems experienced. Results available on request.

${ }^{18}$ Both the 2000 and 2002 figures are computed with weights based on population controls from the 2000 Census rather than the 1990 Census. See note 3.

${ }^{19}$ Logit and ordered logit models yield qualitatively similar results but are harder to interpret.
} 
living in a rural area, race, and ethnicity. The "income controls" model adds household size and family income, both of which could have been affected by either policy changes or labor market conditions.

The "4/95 - 9/2000" columns are based on models pooling surveys from those years and use a linear month-based trend. The "4/1999 - 4/2001" and "4/1999 - 12/2002" columns come from models that use all nine surveys and include a dummy variable for each survey. The estimates in the table show the difference between the relevant year dummies. The standard errors account for the fact that the dummy coefficients are not estimated independently. We then divide both the difference and its standard error by the number of months separating the two data points.

Exogenous controls do not change the picture presented in Figures 2 and 3. Adding income accounts for all of the decline between 1995 and 2000 in the probability that mother-only families would experience either one or three problems, three-fifths of the decline in the probability of experiencing eight problems, and three-fifths of the decline in the total number of problems reported. ${ }^{20}$ These results do not support the prediction that welfare reform would lead to larger reductions in poverty than in material hardship or subsequent claims that rising employment among single mothers did not raise their material standard of living. ${ }^{21}$

\footnotetext{
${ }^{20}$ We also experimented with controls for mothers' labor force status, employment, age, and education. None of these additional variables had any important effect net of income on the trends we describe. Descriptive statistics for all our dependent and independent variables are provided in Appendix Table A.3. Detailed regression results available from the authors upon request.

${ }^{21}$ Other regression results (not shown) indicate that working single mothers experienced significantly fewer food-related problems than single mothers with the same income who are not working. Since women who work surely have work-related expenses, this finding presumably means that working is associated either with spending less on non-food consumption or with better management of the same grocery budget.
} 
Table 2 actually shows a larger decline in severe hardship than the CPS income measure predicts. If this decline were due to biases in the Consumer Price Index, failure to report EITC refunds, or unreported help from newly employed boyfriends, we should also see an unexplained decline in the proportion of single mothers experiencing milder hardships, which we do not. Because the unexplained decline is limited to severe hardships, our tentative explanation is that our categorical income measure is not very good at capturing changes in the resources available to the worst off single mothers. This hypothesis is supported by the fact that the relationship between income and food insecurity among families near the bottom of the distribution is remarkably flat. More detailed income measures derived from the March CPS and the decennial Census show the same pattern. None of these measures is likely to capture changes in child care subsidies, EITC refunds, food stamps, housing subsidies, or cohabiting boyfriends' earnings, which can be critical to food-related problems among mothers with low earnings and cash benefits.

The picture changes after April 1999. The last four columns of Table 2 suggest that single mothers' food problems did stop falling after April 1999, even though their mean purchasing power continued to rise. The four summary measures in Table 2 suggest that if we ignore income single mothers' food-related problems did not change significantly between April 1999 and April 2001. Once we control per capita income, however, all four measures of food-related problems increase, and the increases in severe hardship are statistically significant. This does not mean single mothers were worse off, but it does mean that they gained less than one would have expected given the increase in their inflation-adjusted income. 
This argument becomes even stronger when we examine changes between April 1999 and December 2002, which is the most recent survey available. Prior to controlling income, all four measures suggest small, statistically insignificant increases in hardship, but once we control for income, the unexplained increases in material hardship are all larger and are significant at the 0.05 level. Overall, therefore, income changes underestimate the change in food-related problems from 1995 to 1999 and over-estimate the change from 1999-2002.

Taken as a whole, our findings suggest that the material well-being of mother-only families improved markedly between 1995 and 2000, and especially between 1995 and 1997. Measured income gains explain some but not all of the improvement between 1995 and 2000. Better measures of the resources available to the poorest households might well explain the rest. The reduction in food-related problems appears to have ceased sometime between April 1999 and April 2001, and food-related problems rose slightly between April 2001 and December 2002. The evidence from the FSS is thus consistent with official poverty statistics, which also show a small uptick in poverty between 2000 and 2002. Nonetheless, single mothers and their children experienced substantially less poverty and fewer food-related problems during 2002 than in 1995.

\section{Comparing Mother-Only and Two-Parent Families}

During the year prior to the April 1995 FSS, unemployment averaged almost six percent. In 2000, unemployment averaged 4.0 percent. By 2002 it again averaged almost six percent, but real wages at the $20^{\text {th }}$ percentile of the distribution were 13 percent higher in 2001 than in 1995 [Mishel, Bernstein, and Boushey, 2003], and were almost certainly still well above their 1995 level in 2002. Many critics have argued that these 
improvements in the labor market account for the entire improvement in single mothers' living conditions, and the improvement would have been even larger in the absence of welfare reform.

This paper does not try to disentangle the effect of welfare reform from the effect of other changes in social policy in the 1990s. We do, however, ask how changes in social policy as a whole dampened or accentuated the effects of improved labor market conditions on single mothers' economic well-being. We begin by comparing trends in food-related problems among mother-only families to trends among two-parent families, since changes in social policy during the 1990s had far more effect on mother-only families than on two-parent families. ${ }^{22}$ This comparison could obviously be misleading if changes in social policy had also changed the fraction of mothers who were married. But the fraction of families with children under eighteen headed by a single mother only rose from 22.2 percent in 1995 to 22.4 percent in $2002 .{ }^{23}$

Table 3 compares food-related problems among mother-only and two-parent families, using the same measures as Table $1 .{ }^{24} \mathrm{We}$ show both percentage point changes and changes in logged odds ratios. Comparing April 2001 to April 1995, all ten of the percentage-point gaps narrow. Nine of the ten measures in Table 3 also show larger

\footnotetext{
${ }^{22}$ In principle, two-parent families were eligible for AFDC-UP (Aid to Families with Dependent ChildrenUnemployed Parent), but only 300,000 families received such benefits in 1996 - less than seven percent of all AFDC families and about one percent of all two-parent families [Committee on Ways and Means, 1998, p. 425; http://www.census.gov/prod/2/pop/p20/p20-495u.pdf]. We also compared single mothers to unmarried, non-elderly women who did not live with related children under the age of eighteen. These comparisons showed greater relative improvement for single mothers than those reported here, but most readers were skeptical about whether single childless women are an appropriate comparison group.

${ }^{23}$ See U.S. Bureau of the Census [2003a]. For evidence on whether welfare reform affected the prevalence of single parenthood see Acs and Nelson [2002], Bavier [2002], Bitler, Gelbach, and Hoynes [2003], Ellwood [2000], Fitzgerald and Ribar [2001], and Schoeni and Blank [2000].
} 
proportional improvements between April 1995 and April 2001 among mother-only families, and for four out of nine the change is statistically significant. Visits to food pantries is the only one of our 27 measures that showed even a marginally significant increase in the logged odds ratio. ${ }^{25}$

If we use the mean number of core problems to summarize the relative frequency of food-related problems for the two groups, the ratio falls from 3.38 in April 1995 to 2.94 in April 2001 and then climbs to 3.30 in December 2002. The former is significant at the 0.05 level, the latter at the 0.10 level. The timing of these changes suggests that the business cycle had more impact on well-being among mother-only families than among two-parent families. We discuss this question in more depth after noting additional checks we made using the FSS data.

\section{Robustness checks}

Severe problems. One possible objection to the findings reported above is that they over-emphasize the most common food-related problems and under-emphasize severe problems. If this were a source of bias, however, relatively rare problems should have fallen proportionately less than more common problems among mother-only families. In fact, proportionate declines in the least common food-related problems were at least as great as those for more common ones, whether we consider the 1995-1999 or 1995-2002 period. Relatively rare problems did increase more in proportional terms after 1999. Both of these findings are consistent with the picture presented thus far.

\footnotetext{
${ }^{24}$ See Appendix Table A.4 for detailed results that include standard errors for two-parent families and trends in the late summer surveys.

${ }^{25}$ These bivariate results are reinforced by multivariate models (not shown).
} 
Furthermore, from April 1995 to April 1999 ten of the twelve "severe" measures we examined improved among mother-only families, although the change was statistically significant for only four measures. ${ }^{26}$ Between April 1999 and December of 2002, ten of the severe measures worsened among mother-only families, although none of the changes were statistically significant.

Problems experienced in the past thirty days. While most FSS questions refer to the twelve months preceding an interview, the questionnaire also asks whether respondents experienced selected problems in the past thirty days. Of our nine "past thirty days" measures, eight improved among mother-only families from 1995 to April 1999. All of these improvements were statistically significant at a level of 0.10 or less. The same eight problems worsened between April 1999 and December 2002, though few changes were statistically significant.

Problems among less-skilled single mothers. Primus et al. [1999] have argued that while incomes rose for many single mothers after 1995, they fell among the poorest ten percent of single mothers. If policy changes increased the dispersion of income among single mothers, food insecurity and insufficiency should have increased among the least employable single mothers while falling for the more employable majority. To test this hypothesis we examined trends in food problems among single mothers with less than twelve years of schooling, a group that comprises the bottom quintile of single mothers in

\footnotetext{
${ }^{26}$ The measures we designate as "severe" include problems that were "often" experienced or experienced in three or more months during the preceding year. The USDA's measure of household hunger is also included in this group.
} 
terms of educational attainment. The trends were largely the same as those for all single mothers, though fewer were statistically significant due to the smaller sample. ${ }^{27}$

Survey limitations. The representativeness of the FSS sample could also have changed over time. Based on our tabulations, however, it appears that the proportion of mothers who passed the pre-core screen but then failed to answer all the core questions was under two percent in each year. Changes in the USDA's screening methodology are also unlikely to explain the trends we find. Responses to two questions asked of all respondents are consistent with those that occur after the screens are applied, and there are no consistent differences between items that occur at different stages of the screening. ${ }^{28}$ Finally, we re-ran our tabulations for $1998-2002$ without applying the common screens. Because the actual screening methodology did not vary from 1998 onwards, these estimates should be comparable across years. The patterns we report do not change when the administered screens are used.

\section{Changes in the relationship between labor market conditions and poverty}

Because rising incomes explain most of the reduction in food-related problems between 1995 and 2000, we need to ask whether single mothers' incomes rose because of social policy changes, the unusually tight labor market, or a combination of the two. One common approach to assessing the impact of welfare reform per se has been to look at the results of various randomized experiments that included rule changes similar to those that

\footnotetext{
${ }^{27}$ Results not shown. We restrict the sample on the basis of education because poverty status is more likely to be endogenous over the period. We examined trends in educational attainment for our sample to confirm that there were no large changes in the proportion of mothers with a high-school education.

${ }^{28}$ Appendix Table A.1 gives the proportion of the FSS sample screened out by each of the screens.
} 
states made under PRWORA. A second approach has been to take advantage of the fact that both the waivers granted between 1992 and 1996 and PRWORA itself gave states considerable discretion regarding both the content and timing of the rules the rules they adopted. Blank [2002] and Grogger, Karoly, and Klerman [2002] provide excellent reviews of both types of studies. These reviews suggest that when labor market conditions remained constant welfare reform led to a small reduction in poverty. But poverty among unmarried female heads with children fell from 41.5 percent in 1995 to 32.5 percent in 2000 [U.S. Bureau of the Census, 2003]. Nothing in either the econometric or experimental literature suggests that policy changes alone could have produced a drop of this magnitude.

Critics of welfare reform often attribute declining poverty rates among single mothers to the unusually tight labor market. Employment among single mothers in the FSS rose from 60.7 percent in April 1995 to 71.0 percent in December 2002, while the employment rate for married mothers was about 67 percent in both surveys. ${ }^{29}$ Among mothers without a high school diploma, employment climbed from 35.8 to 49.5 percent for single mothers but only from 41.0 to 43.3 percent for married mothers (see Appendix Table A.5). In addition, real wages near the bottom of the distribution increased about 2 percent a year between 1995 and 2001. ${ }^{30}$

\footnotetext{
${ }^{29}$ Using the March CPS, Gary Burtless calculates that the employment-to-population ratio among single mothers rose from 0.616 in 1995 to 0.732 in 2001 and then fell to 0.721 in 2002 (Burtless [2004], shows these data graphically.)

${ }^{30}$ For trends in hourly wages at the 10th and 20th percentiles for men and women from 1973 to 2001 see Mishel, Boushey, and Bernstein [2003]. In the FSS, real incomes appear to rise by about $\$ 5,000$ among both working and non-working single mothers between 1995 and 2002, although the categorical income measure makes this estimate imprecise. This measure was produced by assigning mothers to the midpoint of their reported income category and then inflating to constant 2003 dollars.
} 
But these facts alone do not tell us what would have happened to poverty among single mothers in the absence of social policy changes, since tight labor markets might not have raised employment as much in the absence of such changes. Table 4 shows the relationship between unemployment and poverty since $1961 .^{31}$ Periods of falling unemployment are shown in bold. Periods of rising unemployment are shown in regular type. The first column of Table 4 shows the trough-to-peak and peak-to-trough elasticities of the poverty rate for female heads with children relative to the overall civilian unemployment rate. The second column shows this elasticity for married couples with children. ${ }^{32}$ The third column shows the ratio of the two elasticities. Until the 1990s, the elasticity of poverty with respect to aggregate unemployment is much larger for married couples with children than for unmarried female heads with children. That is, of course, what we would expect when a large fraction of female heads receive welfare. These findings are consistent with welfare being both a safety net in bad times and a poverty trap in good times.

The elasticity of poverty with respect to the unemployment rate rose sharply in the 1990s among unmarried female heads. In the late 1990s this elasticity was actually higher among female heads than among married parents. This change is consistent with what we would expect if changes in social policy had made single mothers' incomes more dependent on their labor market opportunities.

\footnotetext{
${ }^{31}$ Since the lags between changes in unemployment, changes in employment, and changes in wages are not always the same, we calculated elasticities from trough to peak to trough, ignoring intermediate years. We also ignored the brief and modest drop in unemployment between 1971 and 1973.

${ }^{32}$ Because the Census Bureau does not report poverty rates for married couples with children until 1974, the estimates for 1961-69 and 1969-75 include both married couples and unmarried men with children. Married couples account for 97.9 percent of the families in this category in 1975 and 98.4 percent in 1961.
} 
The contrast between 1992-96 and 1996-2000 is especially instructive. Between 1992 and 1996 unemployment fell from 7.5 to 5.4 percent, but welfare reform affected relatively few states, rule changes were often modest by post-1996 standards, and the welfare rolls fell only 8 percent (from 4.8 to 4.4 million families). During this period the elasticity of the poverty rate among single female head with respect to aggregate unemployment was 0.30 , which was consistent with experience during earlier economic recoveries. The big change came between 1996 and 2000. Unemployment only fell from 5.4 to 4.0 percent during this period, but welfare reform was implemented in all fifty states, rule changes were more dramatic, and the rolls fell by half (from 4.4 to 2.2 million families). For the years between 1996 and 2000 the elasticity of poverty among unmarried female heads with respect to aggregate unemployment jumped to 0.85. Part this change reflects the fact that real wages for unskilled workers began rising in the late 1990s - something that had not happened since the 1960s. But even in the 1960s the elasticity of poverty among female heads with children was only 0.34 , which was less than a quarter the elasticity for other families with children in the 1960s. In the late 1990s, in contrast, the elasticity was larger for female heads with children than for married couples with children. ${ }^{33}$

Table 4 suggests that the relationship between poverty and labor market conditions changed among single mothers in the late 1990s. A rigorous test of the reasons for that change is beyond the scope of this paper. In the absence of such a test, however, our tentative conclusion is that while falling unemployment and rising real wages would have

\footnotetext{
${ }^{33} \mathrm{We}$ also regressed the logged unemployment rate for women who maintain families with children on the overall logged civilian unemployment rate and a post-1996 linear trend. The coefficient on the logged civilian rate was $0.74(\mathrm{t}=15.8)$. The coefficient on the post-1996 trend was $-0.05(\mathrm{t}=-6.7)$, implying that
} 
lowered poverty among single mothers in the late 1990s even in the absence of policy changes, the decline would have been far smaller. Our conclusion, in short, is that neither policy changes alone nor improvements in job opportunities alone can explain what happened. Nor were their effects simply additive. Rather, it was the multiplicative interaction between tight labor markets and policies aimed at "making work pay" that drove down poverty and material hardship among single mothers in the late 1990s.

\section{Conclusions}

Our findings provide no evidence that policy changes aggravated food-related problems among single mothers or their children between 1995 and 2002. Food-related problems declined a lot between 1995 and 2000, and they only rose a little between 2000 and 2002. These improvements are partly explained by changes in income, but the changes between 1995 and 2000 are sometimes larger than our imperfect measure of income predicts, while subsequent changes are smaller than our measure of income predicts.

Past economic booms had reduced married-couple poverty proportionately faster than mother-only poverty. The boom of the late 1990s reduced poverty proportionately faster among single mothers. There are plausible reasons for thinking that this change was attributable to policy changes. This paper does not test that hypothesis in a rigorous way, but other studies that focus explicitly on this issue seem to us to point in the same direction [Blank, 2002].

unemployment for single mothers declined by an additional 5 percent a year beyond what the historical relationship between their unemployment rates and the civilian rate would have led us to expect. 
During the 1990s skeptics often argued that an economic downturn would be the ultimate test of welfare reform. Our estimates of poverty and food-related problems go through December 2002, when unemployment reached 6.0 percent. Substantially fewer single mothers were either poor or food insecure in December 2002 than in April 1995. In economic terms, the social policy changes of the 1990s appear to have helped more single mothers and harmed fewer than most observers (including the authors of this paper) expected. 


\section{Bibliography}

Acs, Gregory and Sandi Nelson (2002), “Assessing the Relationship between Welfare

Policies and Changes in Living Arrangements of Low-Income Families and Children in the Late 1990s," Assessing the New Federalism Discussion Paper No. 02-05

(Washington, DC, Urban Institute).

Administration for Children and Families (2002), Cash Assistance for Needy Families Aid to Families with Dependent Children (AFDC) and Temporary Assistance for Needy Families (TANF): Average Monthly Families and Recipients for Calendar Years 19362001, www.acf.hhs.gov/news/stats/3697.htm (Washington, DC: U.S. Department of Health and Human Services).

Bavier, Richard (2002), “The Impact of Welfare Reform on Families in Data from the Survey of Income and Program Participation," unpublished manuscript (Washington, DC: Office of Management and Budget).

Bhattacharya, Jayanta, Janet Currie, and Steven Haider (2002), "Food Insecurity or Poverty?: Measuring Need-Related Dietary Adequacy,” NBER Working Paper 9003 (Cambridge, MA: National Bureau of Economic Research). 
Bitler, Marianne P., Jonah B. Gelbach, and Hilary W. Hoynes (2003), "Welfare Reform and Children's Living Arrangements," Labor and Population Working Paper No. 03-28 (Santa Monica, CA: RAND Corporation).

Blank, Rebecca (2002), “Evaluating Welfare Reform in the United States,” Journal of Economic Literature 40, pp. 1105-1166.

Burtless, Gary (2004), “The Labor Force Status of Mothers Who Are Most Likely to Receive Welfare: Changes Following Reform," Web Editorial, http://www.brookings.edu/dybdocroot/views/op-ed/burtless/20040330.pdf (Washington, DC: Brookings Institution).

Cohen, Barbara, James Parry, and Kenneth Yang (2002), Household Food Security in the United States, 1998 and 1999: Detailed Statistical Report (Washington, DC: Food and Consumer Service, US Department of Agriculture).

Committee on Ways and Means, US House of Representatives (1998), 1998 Green Book: Background Materials and Data on Programs within the Jurisdiction of the Committee on Ways and Means (Washington, DC: Government Printing Office).

Council of Economic Advisors (2002), Economic Report of the President (Washington, DC: Government Printing Office). 
Edin, Kathryn and Laura Lein (1997), Making Ends Meet (New York, NY: Russell Sage Foundation).

Ellwood, David (2000), “The Impact of the Earned Income Tax Credit and Social Policy Reforms on Work, Marriage, and Living Arrangements," National Tax Journal 53, pp. 1063-1105.

Fitzgerald, John M. and David C. Ribar (2001), “The Impact of Welfare Waivers on Female Headship Decisions,” Working Paper No. 247 (Chicago, IL: Joint Center for Poverty Research).

Grogger, Jeffrey, Lynn A. Karoly, and Jacob Alex Klerman (2002), Consequences of Welfare Reform: A Research Synthesis (Santa Monica, CA: RAND Corporation).

Hamilton, William L. et al. (1997), "Household Food Security in the United States in 1995,” Technical Report of the Food Security Measurement Project (Washington, DC: Food and Consumer Service, US Department of Agriculture).

Jencks, Christopher, Susan E. Mayer, and Joseph Swingle (2004), “Who Has Benefited from Economic Growth in the United States Since 1969? The Case of Children," in Edward Wolff, editor, What Has Happened to the Quality of Life in American and other Advanced Industrial Nations?, Edward Elgar. 
Jencks, Christopher (1997), “The Hidden Paradox of Welfare Reform,” The American Prospect 8(32), pp. 33-40.

Meyer, Bruce D. and James X. Sullivan (2004), "The Effects of Welfare and Tax Reform: The Material Well-Being of Single Mothers in the 1980s and 1990s," Journal of Public Economics 88, pp. 1387-1420.

Meyer, Bruce D. and James X. Sullivan (2003), "Measuring the Well-Being of the Poor Using Income and Consumption," NBER Working Paper 9760 (Cambridge, MA: National Bureau of Economic Research).

Mishel, Lawrence, Jared Bernstein, and Heather Boushey (2003), The State of Working America 2002/2003 (Ithaca, NY: Cornell University Press).

Nord, Mark (2003), “Keeping Warm, Keeping Cool, Keeping Food on the Table:

Seasonal Food Insecurity and Costs of Heating and Cooling," Paper presented at the Annual Meeting of the National Association for Welfare Research and Statistics, San Diego, CA, July 13-16, 2003.

Nord, Mark, Margaret Andrews, and Steven Carlson (2002), "Household Food Security in the United States, 2001," Food Assistance and Nutrition Research Report No. 29 (Washington, DC: Food and Rural Economics Division, Economic Research Service, U.S. Department of Agriculture). 
Nord, Mark, Margaret Andrews, and Steven Carlson (2003), "Household Food Security in the United States, 2002," Food Assistance and Nutrition Research Report No. 35 (Washington, DC: Food and Rural Economics Division, Economic Research Service, U.S. Department of Agriculture).

Nord, Mark and Kathleen Romig (2003), "Hunger in the Summer: Seasonal Food Insecurity and the National School Lunch and Summer Food Service Programs," Paper presented at the Annual APPAM Research Conference, Washington, DC, November 6-8, 2003.

Ohls, James, Larry Radbill, and Allen Schirm (2001), Household Food Security in the United States, 1995-1997: Technical Issues and Statistical Report (Washington, DC: Food and Consumer Service, US Department of Agriculture).

Primus, Wendell, Lynette Rawlings, Kathy Larin, and Kathryn Porter (1999), The Initial Impacts of Welfare Reform on the Economic Well-Being of Single Mothers' Families (Washington, DC: Center on Budget and Policy Priorities).

Schoeni, Robert F. and Rebecca M. Blank (2000), "What Has Welfare Reform Accomplished? Impacts on Welfare Participation, Employment, Income, Poverty, and Family Structure," NBER Working Paper No. 7627 (Cambridge, MA: National Bureau of Economic Research). 
US Bureau of the Census (2003a), Historical Family Time Series Tables, http://www.census.gov/population/socdemo/hh-fam/tabFM-1.xls (Washington, DC: Department of Commerce).

US Bureau of the Census (2003b), Historical Poverty Tables, www.census.gov/hhes/poverty/histpov/hstpov4.html (Washington, DC: Department of Commerce). 


\section{Appendix A}

Food Security Supplement Screening Methodology. In order to reduce respondent burden, the Food Security Supplement uses screens that attempt to minimize the number of questions a respondent must answer. From 1995 to 1997 the FSS used a single screen that considered responses to the initial food insecurity and insufficiency questions as well as the respondent's family income. If a respondent gave little evidence that her household had experienced any food-related problems, the survey interviewer skipped the core section of the FSS. Beginning in 1998, USDA added two additional screens within the core section of eighteen items. These items are generally asked in increasing order of severity. Respondents who indicate few problems in an early stage are skipped through subsequent stages.

Screening assumes that if respondents do not report relatively common problems they will not report rarer problems. Since this is not completely true, a few households are screened out even though they would have reported additional food-related problems in the absence of the screens. The screens therefore introduce a small downward bias in estimates of the extent of food-related problems. Appendix Table A.1, lines 7-9, shows the percent of the FSS sample removed by each screen in each year.

The screening criteria changed between 1995 and 1997, and the entire methodology changed in 1998, when the additional screens were added. Such inconsistency affects year-to-year comparisons, because different proportions of the sample were questioned about relatively severe problems in different years. To address this problem, USDA has constructed a set of "common screens" that may be applied post hoc to each year's 
sample. The common screen includes an initial screen before the core section of the FSS, and two internal screens within the core. The common screens have the effect of screening out some households that actually answered relatively severe questions (because they passed through the screen that was administered in the year they were surveyed). Although this biases estimates of food insecurity and insufficiency downward, it should make the bias more uniform over time. Appendix Table A.1 shows the effects of the three common screens each year, expressed as the percentage of the FSS sample removed (lines 10-12). All data in this paper is based on using the common screens.

Standard Error Estimates. Because the CPS uses a complex sample design that includes stratification, clustering, and post-stratification adjustment, formulas that assume a simple random sample yield standard errors that are too small. Bootstrapping and similar replication techniques will also fail to produce appropriate standard errors if they do not account for the CPS's sample design. Such an accounting requires statistical packages with capabilities beyond those typically used by researchers.

An alternative to these replication methods is to use the "generalized variance parameters" published by the Census Bureau to estimate standard errors. These parameters deflate the weighted number of observations in a standard error formula to what the unweighted number of observations would be if the CPS were a simple random sample that produced the same variance of sample estimates as the complex CPS sample does. Standard errors can then be recomputed based on this deflated sample size. 
The Census Bureau estimates the generalized variance parameters for groups of related variables, using replication and regression methods on several years of CPS data. Different parameters are provided for different groups of variables, such as educational attainment variables, and for different populations (e.g., persons, families, movers, etc.). One must select the parameter that is most appropriate for one's analysis. For each year we chose the parameter appropriate for analyses of family-level characteristics, using the most conservative such parameters available in the March Demographic Supplement to the CPS (those associated with measuring poverty). We obtained our parameters from the March Supplement rather than from the FSS because the parameters from the latter survey do not account for the loss of sample that occurs as a result of FSS nonparticipation. We inflated the March parameters for each year by the ratio of the CPS sample size to the FSS sample size in order to account for the sample loss. Inflating the parameters deflates our sample sizes further, making our standard errors correspondingly larger. ${ }^{34}$

While the standard errors in our multivariate models account for the fact that a single household may contain more than one family—and so observations are not independent — they do not fully account for the complex CPS sample design. We kept this in mind in interpreting any results that were only marginally statistically significant.

\footnotetext{
${ }^{34}$ We are indebted to Mark Nord for suggesting this procedure. In an earlier draft of this paper, we used generalized variance parameters that were even more conservative -- ones associated with household-level characteristics. A subsequent comparison against USDA reports that used replication techniques indicated that the standard errors produced were too conservative [see Ohls et. al., 2001; Cohen et. al., 2002].
} 
Figure 1: Welfare Families as a Percent of Families Headed by Single Mothers and Poverty Rate for Single Mothers: 1962 to 2002

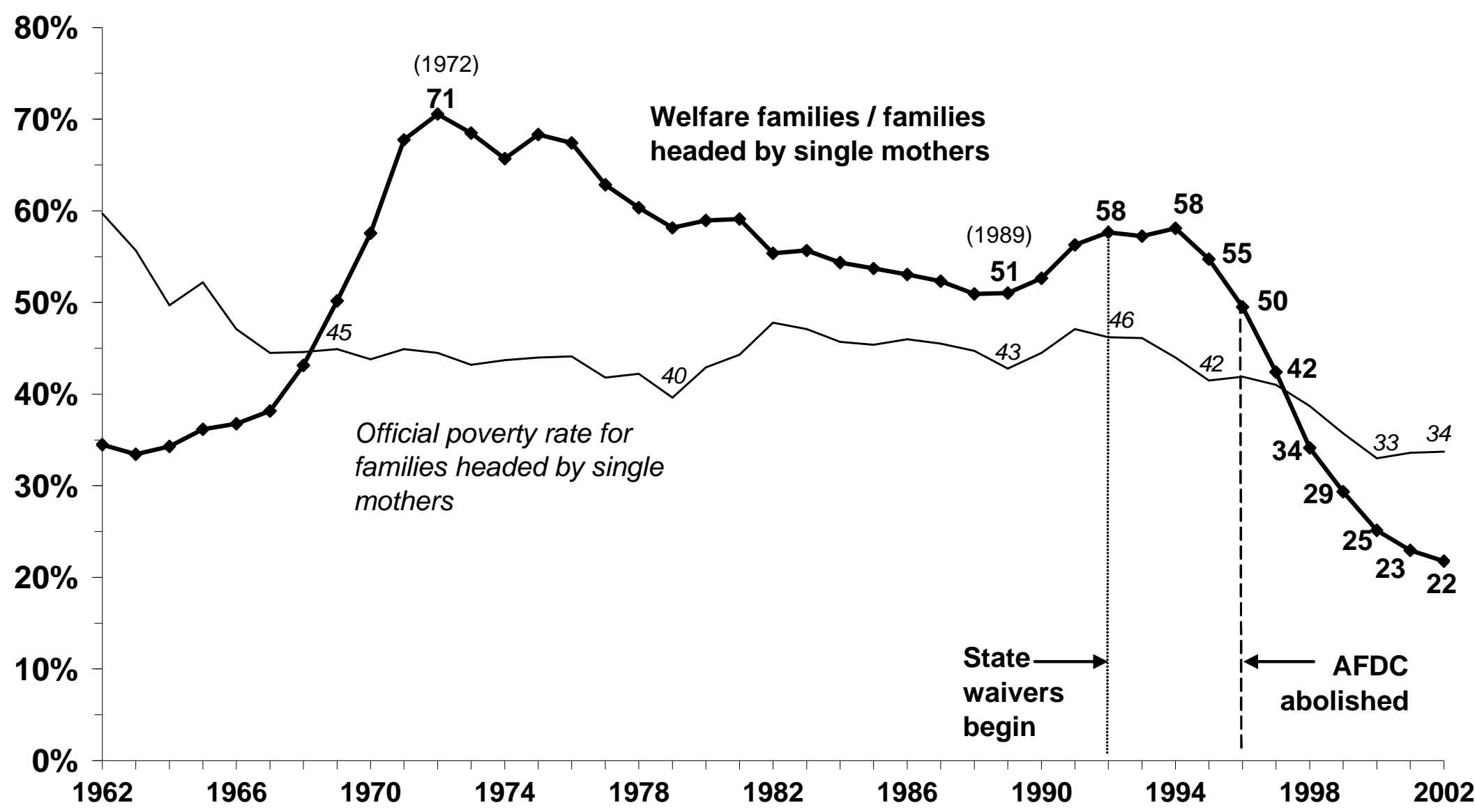

Sources: US Bureau of the Census (2003b) and Administration for Children and Families (2003). TANF figures for 2002 are based on January-September. 
Figure 2: Proportion of Mother-Only and Two-Parent Families with Food Insecurity, April 1995 - Dec. 2002

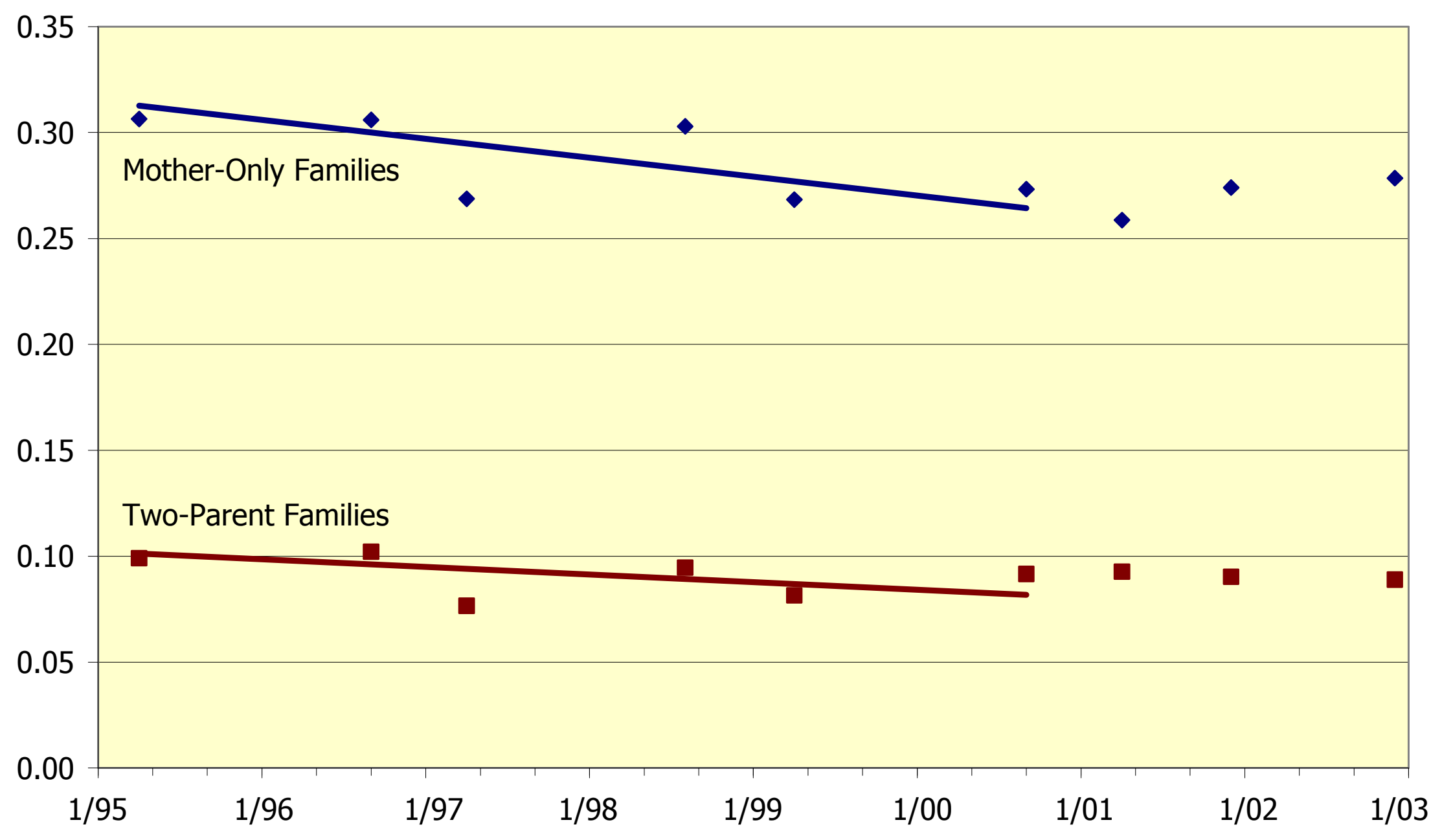

Note: Black diamonds denote survey means with no seasonal adjustment. Trend line indicates 1995-2000 trend with a seasonal adjustment. 
Figure 3: Proportion of Mother-Only and Two-Parent Families with Eight or More Problems, April 1995 - Dec. 2002

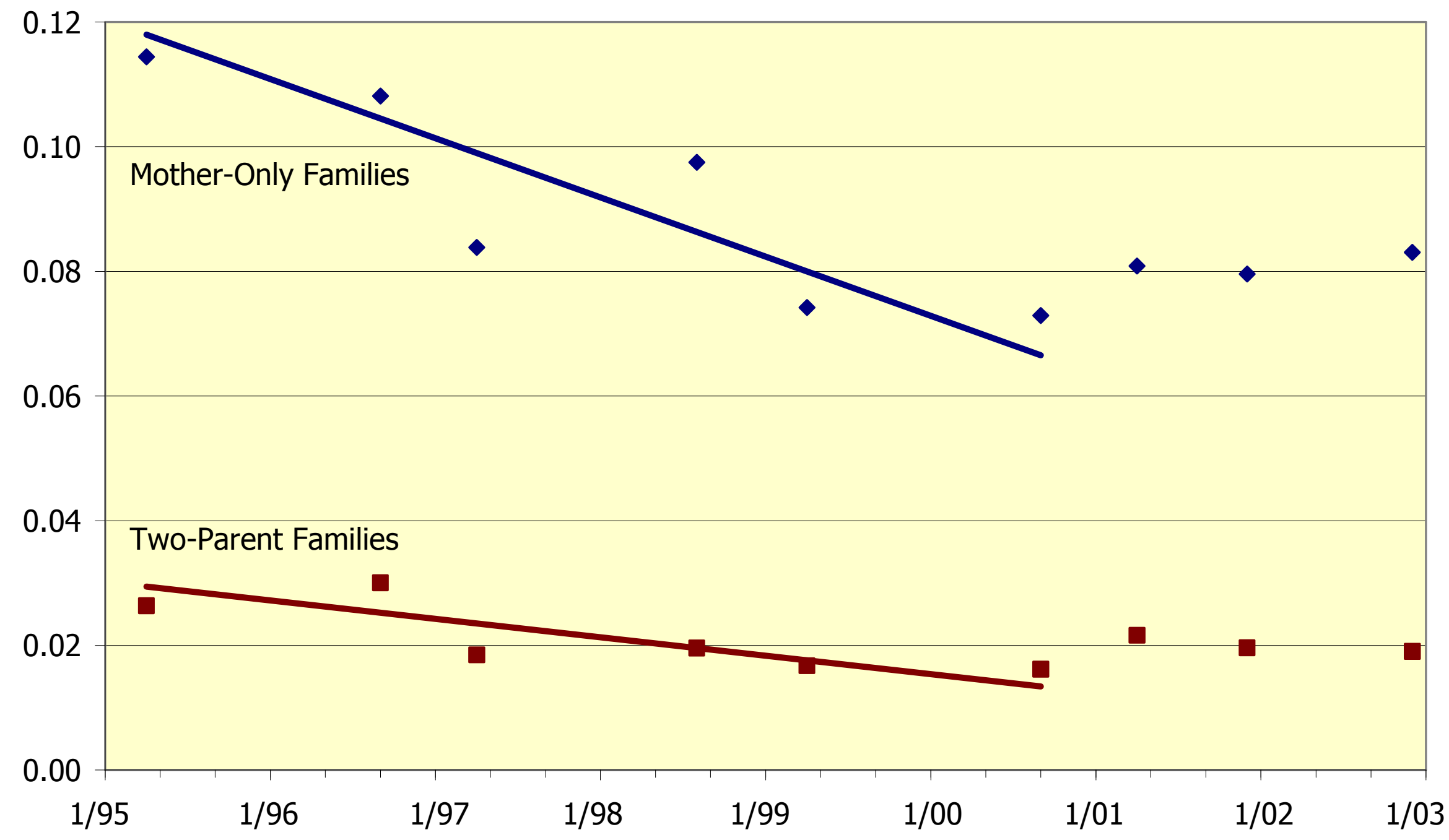

Note: Black diamonds denote survey means with no seasonal adjustment. Trend line indicates 1995-2000 trend with a seasonal adjustment. 
Table 1: Percent of Mother-Only Families with Various Food-Related Problems: April 1995 to December 2002

Significance of change $(\mathbf{P})$

\begin{tabular}{rrrrrrrrrrrr} 
April & April & April & April & Dec. & Dec. & $4 / 95-$ & $4 / 95-$ & $4 / 97-$ & $4 / 99-$ & $4 / 01-$ & $12 / 01-$ \\
1995 & 1997 & 1999 & 2001 & 2001 & 2002 & $4 / 01$ & $4 / 97$ & $4 / 99$ & $4 / 01$ & $12 / 01$ & $12 / 02$ \\
\hline
\end{tabular}

\section{Full sample}

Ran Short Of Money, Stretched Food

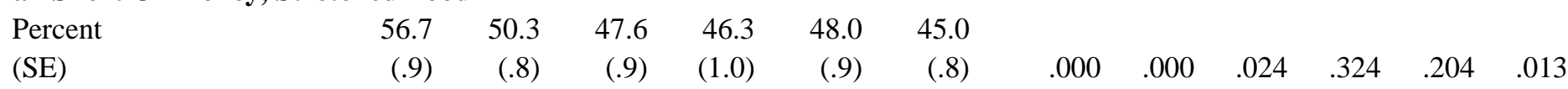

\section{Screened sample}

Mean number of core problems (0-18)

\begin{tabular}{|c|c|c|c|c|c|c|c|c|c|c|c|c|}
\hline $\begin{array}{l}\text { Number } \\
\text { (SE) }\end{array}$ & $\begin{array}{l}2.33 \\
(.06)\end{array}$ & $\begin{array}{l}1.89 \\
(.07)\end{array}$ & $\begin{array}{l}1.83 \\
(.06)\end{array}$ & $\begin{array}{l}1.84 \\
(.07)\end{array}$ & $\begin{array}{l}1.89 \\
(.05)\end{array}$ & $\begin{array}{l}1.94 \\
(.05)\end{array}$ & .000 & .000 & .521 & .871 & .610 & .476 \\
\hline \multicolumn{13}{|c|}{ Food Insecure - USDA } \\
\hline $\begin{array}{l}\text { Percent } \\
\text { (SE) }\end{array}$ & $\begin{array}{r}30.6 \\
(.8)\end{array}$ & $\begin{array}{l}26.9 \\
(1.0)\end{array}$ & $\begin{array}{r}26.8 \\
(.9)\end{array}$ & $\begin{array}{r}25.9 \\
(.9)\end{array}$ & $\begin{array}{r}27.4 \\
(.8)\end{array}$ & $\begin{array}{r}27.9 \\
(.7)\end{array}$ & .000 & .003 & .982 & .434 & .193 & 672 \\
\hline \multicolumn{13}{|c|}{ Worried Food Would Run Out } \\
\hline $\begin{array}{l}\text { Percent } \\
\text { (SE) }\end{array}$ & $\begin{array}{r}38.7 \\
(.8)\end{array}$ & $\begin{array}{r}34.4 \\
(.8)\end{array}$ & $\begin{array}{r}33.1 \\
(.8)\end{array}$ & $\begin{array}{c}31.5 \\
(1.0)\end{array}$ & $\begin{array}{r}33.7 \\
(.8)\end{array}$ & $\begin{array}{r}34.5 \\
(.8)\end{array}$ & .000 & .000 & .267 & .196 & .080 & .517 \\
\hline
\end{tabular}

Got or Borrowed Food From Others

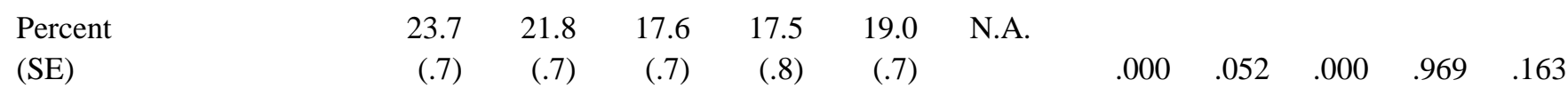

Got Emergency Food From Food Pantry

$\begin{array}{lllllllllllll}\text { Percent } & 9.0 & 6.9 & 7.1 & 8.0 & 8.2 & 8.3 & & & & & \\ \text { (SE) } & (.5) & (.4) & (.4) & (.6) & (.5) & (.5) & .185 & .001 & .768 & .182 & .816 & .843\end{array}$

Adult Cut Size of Or Skipped Meal

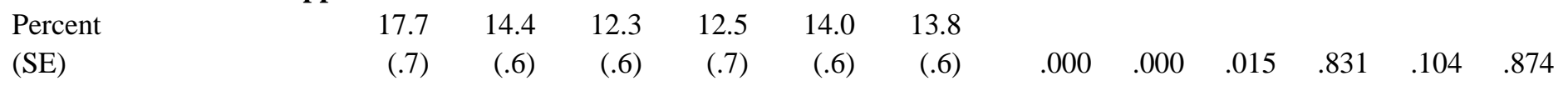

Respondent Lost Weight Due to Poverty

\begin{tabular}{|c|c|c|c|c|c|c|c|c|c|c|c|c|}
\hline $\begin{array}{l}\text { Percent } \\
\text { (SE) }\end{array}$ & $\begin{array}{l}4.5 \\
(.4)\end{array}$ & $\begin{array}{l}3.7 \\
(.3)\end{array}$ & $\begin{array}{l}2.7 \\
(.3)\end{array}$ & $\begin{array}{l}3.6 \\
(.4)\end{array}$ & $\begin{array}{l}3.1 \\
(.3)\end{array}$ & $\begin{array}{l}3.7 \\
(.3)\end{array}$ & .092 & .121 & .016 & .063 & .376 & .173 \\
\hline \multicolumn{13}{|c|}{ Child Not Eating Enough } \\
\hline $\begin{array}{l}\text { Percent } \\
\text { (SE) }\end{array}$ & $\begin{array}{r}10.6 \\
(.5)\end{array}$ & $\begin{array}{l}7.8 \\
(.5)\end{array}$ & $\begin{array}{l}9.0 \\
(.6)\end{array}$ & $\begin{array}{l}7.8 \\
(.6)\end{array}$ & $\begin{array}{l}7.9 \\
(.5)\end{array}$ & $\begin{array}{l}8.1 \\
(.5)\end{array}$ & .000 & .000 & .088 & .119 & .912 & 699 \\
\hline \multicolumn{13}{|c|}{ Child Went Hungry for Day } \\
\hline $\begin{array}{l}\text { Percent } \\
\text { (SE) }\end{array}$ & $\begin{array}{l}4.0 \\
(.3)\end{array}$ & $\begin{array}{r}2.4 \\
(.3)\end{array}$ & $\begin{array}{l}1.8 \\
(.3)\end{array}$ & $\begin{array}{l}1.9 \\
(.3)\end{array}$ & $\begin{array}{l}1.6 \\
(.2)\end{array}$ & $\begin{array}{r}2.1 \\
(.2)\end{array}$ & .000 & .001 & .138 & .676 & .309 & .114 \\
\hline
\end{tabular}

Source: Food Security Supplement to the Current Population Survey, 1995-2002.

Unweighted annual samples range from 2,738 to 4,371. Standard errors account for the CPS design

effects. See Appendix Table A4 for summer survey results and results for two-parent families. 
Table 2: OLS Estimates of Monthly Change in Four Measures of Single Mothers' Food-Related Problems

\begin{tabular}{|c|c|c|c|c|c|c|}
\hline & \multicolumn{2}{|c|}{ 4/1995 to $9 / 2000$} & \multicolumn{2}{|c|}{$4 / 1999$ to $4 / 2001$} & \multicolumn{2}{|c|}{$4 / 1999$ to $12 / 2002$} \\
\hline & $\begin{array}{l}\text { Exogenous } \\
\text { Controls }\end{array}$ & $\begin{array}{l}\text { Income } \\
\text { Controls }\end{array}$ & $\begin{array}{l}\text { Exogenous } \\
\text { Controls }\end{array}$ & $\begin{array}{l}\text { Income } \\
\text { Controls }\end{array}$ & $\begin{array}{l}\text { Exogenous } \\
\text { Controls }\end{array}$ & $\begin{array}{l}\text { Income } \\
\text { Controls }\end{array}$ \\
\hline $\begin{array}{l}\text { At least one problem } \\
(\mathrm{SE})\end{array}$ & $\begin{array}{l}-.0016 \\
(.0002)\end{array}$ & $\begin{array}{c}.0000 \\
(.0002)\end{array}$ & $\begin{array}{l}-.0006 \\
(.0006)\end{array}$ & $\begin{array}{c}.0005 \\
(.0006)\end{array}$ & $\begin{array}{c}.0001 \\
(.0003)\end{array}$ & $\begin{array}{c}.0008 \\
(.0003)\end{array}$ \\
\hline $\begin{array}{l}\text { Three or more problems } \\
\text { (SE) }\end{array}$ & $\begin{array}{l}-.0007 \\
(.0002)\end{array}$ & $\begin{array}{c}.0000 \\
(.0002)\end{array}$ & $\begin{array}{l}-.0004 \\
(.0006)\end{array}$ & $\begin{array}{c}.0006 \\
(.0006)\end{array}$ & $\begin{array}{c}.0002 \\
(.0003)\end{array}$ & $\begin{array}{c}.0008 \\
(.0003)\end{array}$ \\
\hline $\begin{array}{l}\text { Eight or more problems } \\
\text { (SE) }\end{array}$ & $\begin{array}{l}-.0008 \\
(.0001)\end{array}$ & $\begin{array}{l}-.0005 \\
(.0001)\end{array}$ & $\begin{array}{c}.0003 \\
(.0003)\end{array}$ & $\begin{array}{c}.0008 \\
(.0004)\end{array}$ & $\begin{array}{l}.0002 \\
(.0002)\end{array}$ & $\begin{array}{c}.0004 \\
(.0002)\end{array}$ \\
\hline $\begin{array}{l}\text { Mean number of problems } \\
\text { (SE) }\end{array}$ & $\begin{array}{r}-.0088 \\
.0014\end{array}$ & $\begin{array}{l}-.0035 \\
.0014\end{array}$ & $\begin{array}{l}.0007 \\
.0041\end{array}$ & $\begin{array}{l}.0082 \\
.0041\end{array}$ & $\begin{array}{l}.0024 \\
.0020\end{array}$ & $\begin{array}{l}.0061 \\
.0020\end{array}$ \\
\hline
\end{tabular}

Coefficients in bold are significant at $<.05$.

Source: FSS microdata, 1995-2002: 31,231 single mothers, 89,771 married mothers. Sample sizes are smaller for models that control income. The estimates for 4/99 to 4/01 and 4/99 to 12/02 are from models with survey year dummies. The 1995-2000 estimates are from models with a linear trend across those years. 
Table 3: Gap between Unmarried Mothers and Married Mothers on Ten Food-Related Problems

\begin{tabular}{|c|c|c|c|c|c|c|c|c|c|c|c|c|}
\hline & \multirow[b]{2}{*}{$\begin{array}{r}\text { April } \\
1995 \\
\end{array}$} & \multirow[b]{2}{*}{$\begin{array}{r}\text { April } \\
1997 \\
\end{array}$} & \multirow[b]{2}{*}{$\begin{array}{r}\text { April } \\
1999 \\
\end{array}$} & \multirow[b]{2}{*}{$\begin{array}{r}\text { April } \\
2001 \\
\end{array}$} & \multirow[b]{2}{*}{$\begin{array}{l}\text { Dec. } \\
2001 \\
\end{array}$} & \multirow[b]{2}{*}{$\begin{array}{l}\text { Dec. } \\
2002\end{array}$} & \multicolumn{6}{|c|}{ Significance of change $(\mathrm{P})$} \\
\hline & & & & & & & $\begin{array}{r}4 / 95- \\
4 / 01 \\
\end{array}$ & $\begin{array}{r}4 / 95- \\
4 / 97 \\
\end{array}$ & $\begin{array}{r}4 / 97- \\
4 / 99 \\
\end{array}$ & $\begin{array}{r}4 / 99- \\
4 / 01 \\
\end{array}$ & $\begin{array}{l}4 / 01- \\
12 / 01 \\
\end{array}$ & $\begin{array}{r}12 / 01- \\
12 / 02 \\
\end{array}$ \\
\hline \multicolumn{13}{|l|}{ Full sample } \\
\hline \multicolumn{13}{|c|}{ Ran Short Of Money, Stretched Food } \\
\hline Mother-Only & 56.7 & 50.3 & 47.6 & 46.3 & 48.0 & 45.0 & & & & & & \\
\hline Two-Parent & 34.6 & 29.0 & 27.5 & 27.0 & 26.4 & 24.1 & & & & & & \\
\hline $\begin{array}{l}\text { Percentage Point Diff. } \\
\text { (S.E.) }\end{array}$ & $\begin{array}{r}22.0 \\
(.99)\end{array}$ & $\begin{array}{l}21.3 \\
(.97)\end{array}$ & $\begin{array}{l}20.1 \\
(.97)\end{array}$ & $\begin{array}{r}19.3 \\
(1.16)\end{array}$ & $\begin{array}{l}21.5 \\
(.98)\end{array}$ & $\begin{array}{l}20.9 \\
(.93)\end{array}$ & .072 & .613 & .366 & .594 & .142 & .630 \\
\hline $\begin{array}{l}\text { Logged Odds Ratio } \\
\text { (S.E.) }\end{array}$ & $\begin{array}{l}0.90 \\
(.04)\end{array}$ & $\begin{array}{l}0.91 \\
(.04)\end{array}$ & $\begin{array}{l}0.87 \\
(.04)\end{array}$ & $\begin{array}{l}0.85 \\
(.05)\end{array}$ & $\begin{array}{l}0.94 \\
(.04)\end{array}$ & $\begin{array}{l}0.94 \\
(.04)\end{array}$ & .374 & .923 & .538 & .674 & .143 & .955 \\
\hline
\end{tabular}

\section{Screened sample}

Mean number of core problems (0-18)

Mother-Only

Two-Parent

Difference

(S.E.)

Ratio

(S.E.)

\section{Food Insecure - USDA}

Mother-Only

Two-Parent

Percentage Point Diff.

(S.E.)

Logged Odds Ratio

(S.E.) $\begin{array}{ll}2.33 & 1.89\end{array}$

$0.69 \quad 0.53$

1.83

0.53

1.64

(.07)

3.38

(.14)

1.36

(.08)

3.57

(.22)

1.30

(.06)

3.44

(.17)

1.84

0.63

1.89

0.59

1.94

0.59

$\begin{array}{lll}1.22 & 1.30 & 1.35\end{array}$

$(.07) \quad(.06) \quad(.06)$

$\begin{array}{lll}2.94 & 3.21 \quad 3.30\end{array}$

(.15) (.14) (.14) $\begin{array}{llllll}.000 & .006 & .528 & .393 & .359 & .505\end{array}$

$\begin{array}{llllll}.035 & .454 & .641 & .031 & .190 & .651\end{array}$

\section{Worried Food Would Run Out}

\section{Mother-Only}

Two-Parent

Percentage Point Diff.

(S.E.)

Logged Odds Ratio

(S.E.)

\section{6}

9.9

20.7

(.86)

1.39

(.05)

$$
26.9
$$$$
7.7
$$

19.2

$$
\text { (1.07) }
$$

1.49

(.07)
26.8

8.2

18.7

(.93)

1.42

(.06)
25.9

9.3

16.6

(.97)

1.23

(.06)
27.4

9.0

18.4

(.82)

1.34

(.05)
27.9

8.9

19.0

$(.80)$

1.38

(.05)

$\begin{array}{llllll}.001 & .268 & .714 & .118 & .160 & .613\end{array}$

$\begin{array}{llllll}.047 & .274 & .473 & .031 & .188 & .606\end{array}$

$\begin{array}{llllll}38.7 & 34.4 & 33.1 & 31.5 & 33.7 & 34.5\end{array}$

$\begin{array}{llllll}12.9 & 10.7 & 10.9 & 11.8 & 11.7 & 11.7\end{array}$

$\begin{array}{llllll}25.8 & 23.7 & 22.2 & 19.7 & 22.1 & 22.7\end{array}$

$\begin{array}{llllll}(.91) & (.86) & (.87) & (1.04) & (.88) & (.85)\end{array}$

$\begin{array}{llllll}1.45 & 1.48 & 1.40 & 1.24 & 1.35 & 1.38\end{array}$

$\begin{array}{llllll}(.05) & (.05) & (.05) & (.06) & (.05) & (.05)\end{array}$

$\begin{array}{llllll}.000 & .095 & .218 & .067 & .085 & .584\end{array}$

$\begin{array}{llllll}.005 & .686 & .238 & .037 & .137 & .696\end{array}$

Got or Borrowed Food From Others

Mother-Only

Two-Parent

Percentage Point Diff.

(S.E.)

Logged Odds Ratio

(S.E.)
23.7

6.8

17.0

(.78)

1.46

(.06)
21.8

$5.5 \quad 4.6$

16.3

(.73)

13.0

(.69)

1.49

(.07)
17.5

$12.7 \quad 13.6 \quad$ N.A.

(.83) $\quad(.71)$

$1.43 \quad 1.43$

(.08) (.06)
N.A.

$\begin{array}{lllll}.000 & .538 & .001 & .787 & .384\end{array}$

$\begin{array}{lllll}.787 & .172 & .356 & .572 & .959\end{array}$ 


\begin{tabular}{|c|c|c|c|c|c|c|c|c|c|c|c|c|}
\hline & $\begin{array}{r}\text { April } \\
1995 \\
\end{array}$ & $\begin{array}{r}\text { April } \\
1997 \\
\end{array}$ & $\begin{array}{r}\text { April } \\
1999 \\
\end{array}$ & $\begin{array}{r}\text { April } \\
2001 \\
\end{array}$ & $\begin{array}{l}\text { Dec. } \\
2001\end{array}$ & $\begin{array}{l}\text { Dec. } \\
2002\end{array}$ & $\begin{array}{r}4 / 95- \\
4 / 01 \\
\end{array}$ & $\begin{array}{r}4 / 95- \\
4 / 97 \\
\end{array}$ & $\begin{array}{r}4 / 97- \\
4 / 99 \\
\end{array}$ & $\begin{array}{r}4 / 99- \\
4 / 01 \\
\end{array}$ & $\begin{array}{l}4 / 01- \\
12 / 01\end{array}$ & $\begin{array}{r}12 / 01- \\
12 / 02 \\
\end{array}$ \\
\hline \multicolumn{13}{|c|}{ Got Emergency Food From Food Pantry } \\
\hline Mother-Only & 9.0 & 6.9 & 7.1 & 8.0 & 8.2 & 8.3 & & & & & & \\
\hline Two-Parent & 2.7 & 1.6 & 1.5 & 1.9 & 2.2 & 2.1 & & & & & & \\
\hline $\begin{array}{l}\text { Percentage Point Diff. } \\
\text { (S.E.) }\end{array}$ & $\begin{array}{r}6.3 \\
(.52)\end{array}$ & $\begin{array}{r}5.3 \\
(.45)\end{array}$ & $\begin{array}{r}5.5 \\
(.46)\end{array}$ & $\begin{array}{r}6.1 \\
(.58)\end{array}$ & $\begin{array}{r}6.0 \\
(.49)\end{array}$ & $\begin{array}{r}6.2 \\
(.48)\end{array}$ & .838 & 163 & .719 & 443 & .865 & .761 \\
\hline $\begin{array}{l}\text { Logged Odds Ratio } \\
\text { (S.E.) }\end{array}$ & $\begin{array}{l}1.26 \\
(.09)\end{array}$ & $\begin{array}{l}1.53 \\
(.11)\end{array}$ & $\begin{array}{l}1.59 \\
(.11)\end{array}$ & $\begin{array}{r}1.50 \\
(.12)\end{array}$ & $\begin{array}{l}1.37 \\
(.10)\end{array}$ & $\begin{array}{l}1.43 \\
(.09)\end{array}$ & .101 & .052 & .692 & .577 & .405 & .682 \\
\hline \multicolumn{13}{|c|}{ Adult Cut Size of Or Skipped Meal } \\
\hline Mother-Only & 17.7 & 14.4 & 12.3 & 12.5 & 14.0 & 13.8 & & & & & & \\
\hline Two-Parent & 5.1 & 3.9 & 3.6 & 3.9 & 4.0 & 4.0 & & & & & & \\
\hline $\begin{array}{l}\text { Percentage Point Diff. } \\
\text { (S.E.) }\end{array}$ & $\begin{array}{l}12.6 \\
(.70)\end{array}$ & $\begin{array}{l}10.5 \\
(.62)\end{array}$ & $\begin{array}{r}8.7 \\
(.68)\end{array}$ & $\begin{array}{r}8.6 \\
(.72)\end{array}$ & $\begin{array}{l}10.0 \\
(.63)\end{array}$ & $\begin{array}{r}9.8 \\
(.60)\end{array}$ & .000 & .030 & .047 & .936 & .149 & .855 \\
\hline $\begin{array}{l}\text { Logged Odds Ratio } \\
\text { (S.E.) }\end{array}$ & $\begin{array}{l}1.38 \\
(.07)\end{array}$ & $\begin{array}{l}1.43 \\
(.07)\end{array}$ & $\begin{array}{l}1.33 \\
(.09)\end{array}$ & $\begin{array}{l}1.27 \\
(.09)\end{array}$ & $\begin{array}{l}1.37 \\
(.07)\end{array}$ & $\begin{array}{l}1.35 \\
(.07)\end{array}$ & .311 & .623 & .375 & .633 & .367 & .855 \\
\hline
\end{tabular}

\section{Respondent Lost Weight Due to Poverty}

$\begin{array}{lrrrrrrrrrrrr}\text { Mother-Only } & 4.5 & 3.7 & 2.7 & 3.6 & 3.1 & 3.7 & & & & & \\ \text { Two-Parent } & 1.0 & 0.8 & 0.6 & 1.0 & 0.7 & 0.7 & & & & & \\ \text { Percentage Point Diff. } & 3.4 & 2.9 & 2.1 & 2.6 & 2.4 & 3.0 & & & & & \\ \text { (S.E.) } & (.37) & (.33) & (.29) & (.40) & (.31) & (.33) & .134 & .325 & .072 & .352 & .753 & .214 \\ \text { Logged Odds Ratio } & 1.50 & 1.59 & 1.61 & 1.33 & 1.53 & 1.66 & & & & & & \\ \text { (S.E.) } & (.13) & (.15) & (.18) & (.17) & (.16) & (.15) & .432 & .650 & .932 & .251 & .398 & .536\end{array}$

\section{Child Not Eating Enough}

Mother-Only

Two-Parent

Percentage Point Diff.

(S.E.)

Logged Odds Ratio

(S.E.)

$\begin{array}{rrrrrr}10.6 & 7.8 & 9.0 & 7.8 & 7.9 & 8.1 \\ 2.7 & 2.1 & 2.3 & 2.9 & 2.3 & 2.2 \\ 7.9 & 5.7 & 6.7 & 4.9 & 5.6 & 6.0 \\ (.56) & (.48) & (.59) & (.59) & (.49) & (.48) \\ 1.46 & 1.35 & 1.44 & 1.04 & 1.31 & 1.38 \\ (.09) & (.10) & (.11) & (.11) & (.10) & (.09)\end{array}$

$\begin{array}{llllll}.000 & .002 & .154 & .027 & .341 & .628\end{array}$

$\begin{array}{llllll}.002 & .424 & .524 & .007 & .058 & .596\end{array}$

\section{Child Went Hungry for Day}

Mother-Only

Two-Parent

Percentage Point Diff.

(S.E.)

Logged Odds Ratio

(S.E.) $\begin{array}{llllll}4.0 & 2.4 & 1.8 & 1.9 & 1.6 & 2.1\end{array}$

$\begin{array}{llllll}0.9 & 0.5 & 0.4 & 0.7 & 0.4 & 0.4\end{array}$

$\begin{array}{llllll}3.1 & 1.9 & 1.3 & 1.2 & 1.2 & 1.7\end{array}$

$\begin{array}{llllll}(.35) & (.36) & (.27) & (.30) & (.22) & (.24)\end{array}$

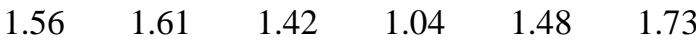

$\begin{array}{llllll}(.15) & (.25) & (.24) & (.21) & (.22) & (.21)\end{array}$ $\begin{array}{llllll}.000 & 019 & .0197 & .804 & .936 & .136\end{array}$

\begin{tabular}{llllll}
.042 & .857 & .588 & .221 & .151 & .403 \\
\hline
\end{tabular}

Source: Food Security Supplement to the Current Population Survey, 1995-2002.

Unweighted annual samples range from 2,738 to 4,371. Standard errors account for the CPS design

effects. See Appendix Table A4 for summer survey results and standard errors for two-parent families. 


\section{Table 4: Percent Changes in Poverty Relative to Percent Change in Unemployment during Four Business Cycles}

\begin{tabular}{|c|c|c|c|}
\hline \multirow[b]{2}{*}{ Period } & \multicolumn{2}{|c|}{$\begin{array}{l}\text { Percent change in poverty / percent } \\
\text { change in unemployment }\end{array}$} & \multirow[b]{2}{*}{$\begin{array}{l}\text { Column 1/ } \\
\text { Column } 2 \\
\end{array}$} \\
\hline & $\begin{array}{l}\text { Female heads } \\
\text { with children }\end{array}$ & $\begin{array}{c}\text { Married } \\
\text { couples with } \\
\text { children } \\
\end{array}$ & \\
\hline $1961-69^{c}$ & .34 & $1.40^{d}$ & .24 \\
\hline $1969-75^{\mathrm{e}}$ & -.02 & $.14^{\mathrm{d}}$ & -.16 \\
\hline $1975-79^{c}$ & .28 & .42 & .65 \\
\hline $1979-82$ & .37 & .90 & .41 \\
\hline $1982-89^{c}$ & .18 & .47 & .39 \\
\hline $1989-92$ & .22 & .46 & .48 \\
\hline $1992-00^{c}$ & .56 & .57 & .99 \\
\hline $1992-96$ & .30 & .43 & .70 \\
\hline 1996-00 & .85 & .72 & 1.17 \\
\hline $2000-02$ & .06 & .27 & .22 \\
\hline
\end{tabular}

a. $\ln \left[\mathrm{P}_{2} /\left[\mathrm{P}_{1}\right] / \ln \left[\mathrm{U}_{2} / \mathrm{U}_{1}\right]\right.$, where $\mathrm{P}$ is the percent poor, $\mathrm{U}$ is the percent unemployed, the subscript 1 designates the beginning of the period, and 2 designates the end.

b. Same as in note a, except that $\mathrm{P}$ is now Percent Poor/(100-Percent Poor) and $\mathrm{U}$ is now Percent Unemployed/(100-Percent Unemployed).

\section{c. Period of falling unemployment.}

d. Estimates for married couples with children for 1961-69 and 1969-75 include unmarried men with children (see text, footnote 32 ).

e. Unemployment rose from 1969 to 1971, declined slightly in 1972-73, and rose fron 1973 to 1975.

Sources: The civilian unemployment rate is from Council of Economics Advisers (20 Poverty rates are from US Bureau of the Census (2003). 
Table A.1: CPS and FSS Sample Sizes, Rates of Nonparticipation, and Effects of Screens

\begin{tabular}{|c|c|c|c|c|c|c|c|c|c|c|}
\hline & & 1995 & 1996 & 1997 & 1998 & 1999 & 2000 & Apr. '01 & Dec. '01 & 2002 \\
\hline \multicolumn{2}{|c|}{1 Potential Sample Size (Households) } & 57,765 & 50,734 & 50,801 & 51,225 & 51,341 & 51,430 & 60,263 & 60,759 & 61,245 \\
\hline \multicolumn{2}{|c|}{2 CPS Participants } & 53,665 & 47,795 & 47,306 & 47,761 & 47,500 & 47,878 & 55,375 & 56,443 & 56,967 \\
\hline \multicolumn{2}{|c|}{3 Nonparticipation in CPS (Percent) } & 7.1 & 5.8 & 6.9 & 6.8 & 7.5 & 6.9 & 8.1 & 7.1 & 7.0 \\
\hline \multicolumn{2}{|c|}{$\begin{array}{l}4 \text { FSS Participants } \\
\text { Nonparticipation in FSS as Percent of: }\end{array}$} & 44,647 & 41,811 & 41,146 & 43,744 & 41,311 & 40,460 & $34,330^{\mathrm{a}}$ & 47,941 & 50,159 \\
\hline 5 & Potential CPS Sample & 22.7 & 17.6 & 19.0 & 14.6 & 19.5 & 21.3 & 23.7 & 21.1 & 18.1 \\
\hline 6 & CPS Participants & 16.8 & 12.5 & 13.0 & 8.4 & 13.0 & 15.5 & 17.4 & 15.1 & 12.0 \\
\hline \multicolumn{11}{|c|}{ Percent Screened by Administered Screen(s) } \\
\hline 7 & Preliminary Screen & \multirow[t]{3}{*}{58.9} & \multirow[t]{3}{*}{73.9} & \multirow[t]{3}{*}{72.9} & 55.0 & 58.1 & 54.3 & 55.2 & 55.3 & 55.7 \\
\hline 8 & First Internal Screen & & & & 25.4 & 24.2 & 27.5 & 26.7 & 26.5 & 26.0 \\
\hline 9 & Second Internal Screen & & & & 11.0 & 10.7 & 10.7 & 10.5 & 10.6 & 10.3 \\
\hline \multicolumn{11}{|c|}{ Percent Screened by Common Screens } \\
\hline 10 & Preliminary Screen & 78.1 & 78.0 & 79.9 & 80.1 & 81.6 & 80.5 & 80.8 & 80.5 & 79.85 \\
\hline 11 & First Internal Screen & 6.7 & 6.8 & 3.3 & 5.1 & 5.0 & 5.8 & 5.6 & 5.7 & 5.9 \\
\hline 12 & Second Internal Screen & 7.3 & 6.9 & 7.3 & 7.1 & 7.0 & 7.0 & 6.9 & 6.9 & 7 \\
\hline
\end{tabular}

Source: 1995-2002 Food Security Supplement to the Current Population Survey. For background on the FSS screening methodology, see the appendix

${ }^{\mathrm{a}}$ The April 2001 FSS was administered to only 3/4 of the CPS sample. 
Table A.2: Food Security Supplement Descriptive Statistics: 1995-2002

(standard errors in parentheses)

\begin{tabular}{|c|c|c|c|c|c|c|}
\hline & \multicolumn{4}{|c|}{ Survey years - April } & \multirow{2}{*}{$\begin{array}{c}\text { December } \\
2001 \\
\end{array}$} & \multirow{2}{*}{$\begin{array}{c}\text { December } \\
2002 \\
\end{array}$} \\
\hline & 1995 & 1997 & 1999 & 2001 & & \\
\hline \multicolumn{7}{|l|}{ Race/Ethnicity } \\
\hline \multicolumn{7}{|l|}{ Mother-Only } \\
\hline \multirow[t]{2}{*}{ Non-Hispanic White } & 50.9 & 49.2 & 50.4 & 50.0 & 51.2 & 50.0 \\
\hline & $(.8)$ & $(1.0)$ & $(1.0)$ & $(1.0)$ & (.9) & (.8) \\
\hline \multirow[t]{2}{*}{ Non-Hispanic Black } & 32.9 & 34.0 & 31.3 & 31.9 & 30.8 & 31.3 \\
\hline & (.8) & (.9) & $(.9)$ & $(1.0)$ & (.8) & $(.8)$ \\
\hline \multirow[t]{2}{*}{ Hispanic } & 13.4 & 13.5 & 15.1 & 14.6 & 14.4 & 15.4 \\
\hline & (.6) & (.7) & (.7) & (.7) & (.6) & (.6) \\
\hline \multirow[t]{2}{*}{ Other } & 2.7 & 3.3 & 3.3 & 3.5 & 3.7 & 3.4 \\
\hline & (.3) & (.3) & (.3) & $(.4)$ & (.3) & $(.3)$ \\
\hline Total & 100.0 & 100.0 & 100.0 & 100.0 & 100.0 & 100.0 \\
\hline \multicolumn{7}{|l|}{ Two-Parent } \\
\hline \multirow[t]{2}{*}{ Non-Hispanic White } & 77.2 & 75.4 & 73.0 & 72.1 & 71.4 & 71.4 \\
\hline & $(.4)$ & $(.5)$ & $(.5)$ & (.6) & $(.5)$ & $(.5)$ \\
\hline \multirow[t]{2}{*}{ Non-Hispanic Black } & 7.5 & 7.7 & 7.7 & 7.9 & 8.3 & 8.3 \\
\hline & (.3) & (.3) & (.3) & (.3) & (.3) & (.3) \\
\hline \multirow[t]{2}{*}{ Hispanic } & 11.6 & 11.8 & 13.7 & 14.0 & 14.2 & 14.4 \\
\hline & (.3) & (.4) & (.4) & (.4) & (.4) & (.4) \\
\hline \multirow[t]{2}{*}{ Other } & 3.7 & 5.1 & 5.5 & 6.0 & 6.2 & 5.9 \\
\hline & $(.2)$ & (.3) & (.3) & (.3) & (.3) & $(.2)$ \\
\hline Total & 100.0 & 100.0 & 100.0 & 100.0 & 100.0 & 100.0 \\
\hline
\end{tabular}

(continued on next page) 
Table A.2. (continued)

\begin{tabular}{|c|c|c|c|c|c|c|c|}
\hline & & \multicolumn{4}{|c|}{ Survey years - spring } & \multirow{2}{*}{$\begin{array}{c}\text { December } \\
2001\end{array}$} & \multirow{2}{*}{$\begin{array}{c}\text { December } \\
2002\end{array}$} \\
\hline & & 1995 & 1997 & 1999 & 2001 & & \\
\hline \multicolumn{8}{|l|}{$\overline{\text { Region }}$} \\
\hline \multicolumn{8}{|l|}{ Mother-Only } \\
\hline & North & 18.5 & 18.9 & 18.8 & 18.8 & 16.9 & 18.0 \\
\hline & & $(.6)$ & $(.8)$ & $(.7)$ & $(.8)$ & (.6) & (.6) \\
\hline & Midwest & 21.9 & 21.7 & 21.3 & 21.0 & 21.5 & 21.7 \\
\hline & & $(.7)$ & $(.8)$ & $(.8)$ & $(.8)$ & $(.7)$ & $(.7)$ \\
\hline & West & 21.3 & 21.5 & 21.4 & 21.2 & 21.7 & 22.0 \\
\hline & & $(.7)$ & $(.8)$ & $(.8)$ & $(.8)$ & $(.7)$ & $(.7)$ \\
\hline & South & 38.3 & 37.9 & 38.5 & 39.0 & 40.0 & 38.4 \\
\hline & & $(.8)$ & $(1.0)$ & $(.9)$ & $(1.0)$ & $(.8)$ & (.8) \\
\hline & Total & 100.0 & 100.0 & 100.0 & 100.0 & 100.0 & 100.0 \\
\hline \multicolumn{8}{|l|}{ Two-Parent } \\
\hline & North & 18.8 & 19.7 & 18.0 & 18.2 & 18.7 & 17.9 \\
\hline & & $(.4)$ & $(.5)$ & $(.4)$ & $(.5)$ & $(.4)$ & $(.4)$ \\
\hline & Midwest & 24.0 & 23.8 & 23.4 & 23.7 & 23.3 & 23.2 \\
\hline & & $(.4)$ & $(.5)$ & $(.5)$ & $(.5)$ & $(.4)$ & (.4) \\
\hline & West & 22.1 & 22.0 & 23.8 & 23.6 & 23.8 & 24.0 \\
\hline & & $(.4)$ & $(.5)$ & $(.5)$ & $(.5)$ & $(.5)$ & (.4) \\
\hline & South & 35.1 & 34.5 & 34.8 & 34.5 & 34.2 & 34.9 \\
\hline & & $(.5)$ & (.6) & $(.6)$ & $(.6)$ & $(.5)$ & $(.5)$ \\
\hline & Total & 100.0 & 100.0 & 100.0 & 100.0 & 100.0 & 100.0 \\
\hline
\end{tabular}

Largest SE of all btwn-year diff's

\section{Region}

Mother-Only

Two-Parent

(continued on next page) 
Table A.2. (continued)

\begin{tabular}{ccccccccc}
\hline & \multicolumn{4}{c}{ Survey years - spring } & December & December & Largest SE of \\
\cline { 2 - 5 } & 1995 & 1997 & 1999 & 2001 & 2001 & 2002 & all btwn-year diff's \\
\hline
\end{tabular}

Metropolitan Residence

Mother-Only

Metropolitan Area

$\begin{array}{rr}65.0 & 67.1 \\ (.8) & (.9) \\ 20.6 & 19.0 \\ (.7) & (.8) \\ 14.4 & 13.9 \\ (.6) & (.7) \\ 100.0 & 100.0\end{array}$

69.3

(.9)

16.9

(.7)

13.8

(.7)

100.0

Total

100.0

61.0

Metropolitan Area

$$
\text { (.5) }
$$

Rural

22.7

(.4)

Uknown

$$
16.3
$$

(.4)

Total

100.0

65.9

(.6)

19.8

(.5)

14.2

(.4)

100.0

67.5

(.5)

18.6

(.5)

13.9

(.4)

100.0

69.9
$(.9)$
16.7
$(.8)$
13.4
$(.7)$
100.0

69.1

(.8)

68.8

17.1

(.8)

(.6) (.6)

13.8

(.6)

(.6) (.6)

$100.0 \quad 100.0$

Mean Mother Age

Mother-Only

33.1

(.1)

36.1

33.8

(.2)

36.5

(.1)

(.1)

33.8
$(.2)$
36.8
$(.1)$

33.9

(.2)

37.3

(.1)

3.68

(.03)

4.21

(.01)

3.69
$(.03)$
4.22
$(.01)$

3.63
$(.03)$
4.23
$(.01)$

3.56

(.03)

4.22

(.01)

-50 -

$\begin{array}{rr}67.9 & 68.2 \\ (.5) & (.5) \\ 18.1 & 17.4 \\ (.4) & (.4) \\ 14.0 & 14.4 \\ (.4) & (.4) \\ 100.0 & 100.0\end{array}$

(.03) (.02)

$\begin{array}{ll}4.21 & 4.24\end{array}$

(.01) (.01)

(continued on next page) 


\begin{tabular}{|c|c|c|c|c|c|c|c|}
\hline & \multicolumn{4}{|c|}{ Survey years - spring } & \multirow{2}{*}{$\begin{array}{c}\text { December } \\
2001\end{array}$} & \multirow{2}{*}{$\begin{array}{c}\text { December } \\
2002\end{array}$} & \multirow{2}{*}{$\begin{array}{l}\text { Largest SE of } \\
\text { all btwn-year diff's }\end{array}$} \\
\hline & 1995 & 1997 & 1999 & 2001 & & & \\
\hline \multicolumn{8}{|l|}{ Family Income } \\
\hline \multicolumn{8}{|l|}{ Mother-Only } \\
\hline Less than $\$ 15,000$ & 51.9 & 47.1 & 41.0 & 31.6 & 33.8 & 33.7 & \\
\hline & (.9) & (1.0) & $(1.0)$ & $(1.0)$ & (.9) & $(.8)$ & (1.4) \\
\hline$\$ 15,000-\$ 39,999$ & 35.9 & 37.4 & 40.1 & 44.4 & 42.3 & 41.9 & \\
\hline & (.8) & $(1.0)$ & $(1.0)$ & (1.1) & (.9) & (.9) & $(1.5)$ \\
\hline$\$ 40,000-\$ 74,999$ & 10.1 & 12.2 & 14.4 & 17.7 & 17.8 & 18.0 & \\
\hline & $(.5)$ & (.7) & $(.7)$ & $(.8)$ & $(.7)$ & $(.7)$ & (1.1) \\
\hline$\$ 75,000+$ & 2.1 & 3.4 & 4.5 & 6.3 & 6.2 & 6.5 & \\
\hline & $(.2)$ & (.4) & (.4) & $(.5)$ & $(.4)$ & (.4) & $(.7)$ \\
\hline Total & 100.0 & 100.0 & 100.0 & 100.0 & 100.0 & 100.0 & \\
\hline
\end{tabular}

Two-Parent

\begin{tabular}{|c|c|c|c|c|c|}
\hline \multirow[t]{2}{*}{ Less than $\$ 15,000$} & 10.6 & 8.6 & 6.7 & 5.3 & 5.7 \\
\hline & $(.3)$ & (.4) & (.3) & $(.3)$ & (.3) \\
\hline \multirow[t]{2}{*}{$\$ 15,000-\$ 39,999$} & 36.0 & 30.9 & 28.1 & 24.9 & 24.4 \\
\hline & $(.5)$ & (.6) & (.6) & $(.6)$ & $(.5)$ \\
\hline \multirow[t]{2}{*}{$\$ 40,000-\$ 74,999$} & 36.0 & 39.4 & 38.3 & 36.6 & 36.2 \\
\hline & $(.5)$ & (.6) & (.6) & (.6) & $(.5)$ \\
\hline \multirow[t]{2}{*}{$\$ 75,000+$} & 17.4 & 21.0 & 26.9 & 33.1 & 33.6 \\
\hline & (.4) & (.5) & $(.5)$ & (.6) & $(.5)$ \\
\hline Total & 100.0 & 100.0 & 100.0 & 100.0 & 100.0 \\
\hline
\end{tabular}

Mean Value of Food Stamps

Mother-Only

$\begin{array}{rrrrrr}82.01 & 71.62 & 58.00 & 46.84 & 47.17 & 55.37 \\ (2.14) & (2.41) & (2.23) & (2.14) & (1.82) & (2.61) \\ 12.39 & 10.29 & 7.63 & 7.28 & 7.76 & 7.62 \\ (.60) & (.63) & (.54) & (.56) & (.51) & (.61)\end{array}$

Two-Parent 


\begin{tabular}{|c|c|c|c|c|c|c|c|}
\hline & \multicolumn{4}{|c|}{ Survey years - spring } & \multirow{2}{*}{$\begin{array}{c}\text { December } \\
2001 \\
\end{array}$} & \multirow{2}{*}{$\begin{array}{l}\text { December } \\
2002\end{array}$} & \multirow{2}{*}{$\begin{array}{c}\text { Largest SE of } \\
\text { all btwn-year diff's }\end{array}$} \\
\hline & 1995 & 1997 & 1999 & 2001 & & & \\
\hline \multicolumn{8}{|l|}{$\overline{\text { Education }}$} \\
\hline \multicolumn{8}{|l|}{ Mother-Only } \\
\hline \multirow[t]{2}{*}{ No High School Diploma } & 24.7 & 23.4 & 20.9 & 19.3 & 19.7 & 20.4 & \\
\hline & $(.7)$ & $(.8)$ & $(.8)$ & $(.8)$ & $(.7)$ & (.7) & $(1.2)$ \\
\hline \multirow[t]{2}{*}{ High School Graduate } & 66.5 & 66.0 & 68.2 & 68.5 & 67.1 & 66.6 & \\
\hline & $(.8)$ & $(.9)$ & (.9) & $(1.0)$ & $(.8)$ & $(.8)$ & $(1.3)$ \\
\hline \multirow[t]{2}{*}{ College Graduate } & 8.8 & 10.6 & 10.9 & 12.2 & 13.2 & 13.0 & \\
\hline & $(.5)$ & (.6) & (.6) & $(.7)$ & (.6) & (.6) & $(.9)$ \\
\hline Total & 100.0 & 100.0 & 100.0 & 100.0 & 100.0 & 100.0 & \\
\hline \multicolumn{8}{|l|}{ Two-Parent } \\
\hline \multirow[t]{2}{*}{ No High School Diploma } & 11.9 & 11.4 & 10.8 & 10.6 & 10.8 & 10.5 & \\
\hline & $(.3)$ & (.4) & (.4) & $(.4)$ & (.3) & (.3) & $(.5)$ \\
\hline \multirow[t]{2}{*}{ High School Graduate } & 63.6 & 61.4 & 60.2 & 60.6 & 59.0 & 57.7 & \\
\hline & $(.5)$ & (.6) & (.6) & (.6) & $(.5)$ & $(.5)$ & $(.8)$ \\
\hline \multirow[t]{2}{*}{ College Graduate } & 24.4 & 27.2 & 29.0 & 28.8 & 30.2 & 31.7 & \\
\hline & (.4) & $(.5)$ & $(.5)$ & (.6) & $(.5)$ & $(.5)$ & $(.8)$ \\
\hline Total & 100.0 & 100.0 & 100.0 & 100.0 & 100.0 & 100.0 & \\
\hline
\end{tabular}


Table A.2. (continued)

\begin{tabular}{|c|c|c|c|c|c|c|c|}
\hline & \multicolumn{4}{|c|}{ Survey years - spring } & \multirow{2}{*}{$\begin{array}{c}\text { December } \\
2001 \\
\end{array}$} & \multirow{2}{*}{$\begin{array}{c}\text { December } \\
2002\end{array}$} & \multirow{2}{*}{$\begin{array}{c}\text { Largest SE of } \\
\text { all btwn-year diff's }\end{array}$} \\
\hline & 1995 & 1997 & 1999 & 2001 & & & \\
\hline \multicolumn{8}{|l|}{ Labor Force Status } \\
\hline \multicolumn{8}{|l|}{ Mother-Only } \\
\hline Employed & 60.7 & 67.0 & 71.5 & 74.0 & 72.2 & 71.0 & \\
\hline & $(.8)$ & $(.9)$ & $(.9)$ & $(.9)$ & $(.8)$ & $(.7)$ & $(1.3)$ \\
\hline Unemployed & 8.1 & 7.5 & 6.2 & 5.2 & 7.2 & 8.2 & \\
\hline & $(.5)$ & $(.5)$ & $(.5)$ & $(.5)$ & $(.4)$ & $(.5)$ & $(.7)$ \\
\hline Out of Labor Force & 31.2 & 25.6 & 22.2 & 20.9 & 20.6 & 20.8 & \\
\hline & $(.8)$ & $(.9)$ & $(.8)$ & $(.8)$ & $(.7)$ & $(.7)$ & $(1.2)$ \\
\hline Total & 100.0 & 100.0 & 100.0 & 100.0 & 100.0 & 100.0 & \\
\hline \multicolumn{8}{|l|}{ Two-Parent } \\
\hline Employed & 67.0 & 68.3 & 68.3 & 67.0 & 67.4 & 66.8 & \\
\hline & $(.5)$ & $(.6)$ & $(.5)$ & $(.6)$ & $(.5)$ & $(.5)$ & $(.8)$ \\
\hline Unemployed & 2.8 & 2.4 & 2.0 & 2.4 & 2.7 & 2.7 & \\
\hline & $(.2)$ & $(.2)$ & $(.2)$ & $(.2)$ & $(.2)$ & $(.2)$ & $(.3)$ \\
\hline Out of Labor Force & 30.2 & 29.3 & 29.8 & 30.6 & 29.9 & 30.5 & \\
\hline & $(.5)$ & $(.5)$ & $(.5)$ & $(.6)$ & $(.5)$ & $(.5)$ & (.8) \\
\hline Total & 100.0 & 100.0 & 100.0 & 100.0 & 100.0 & 100.0 & \\
\hline
\end{tabular}

Source: 1995-2002 Food Security Supplement to the CPS. Family income refers to the household head's family.

Standard errors account for the complex CPS sample design. 


\title{
Table A.3: Descriptive Statistics for Variables Included in Regressions
}

\author{
Models Estimating 1995-2000 Trends
}

\begin{tabular}{lrrrr} 
& \multicolumn{2}{c}{ Mother-Only Families } & \multicolumn{2}{c}{ Two-Parent Families } \\
\cline { 2 - 5 } & \multicolumn{1}{c}{ Mean } & S.D. & Mean & S.D. \\
\hline Dependent Variables & .39 & .49 & .14 & .35 \\
Has One or More Problems? & .29 & .45 & .09 & .29 \\
Food Insecure? (USDA Measure) & .09 & .29 & .02 & .15 \\
Has Eight or More Problems? & 2.07 & 3.38 & .62 & 1.91 \\
Number of Problems (0-18) & & & & \\
& & & & \\
Independent Variables & 33.20 & 22.09 & 33.07 & 22.01 \\
Trend (1= 4/1995, 81=12/2001) & .53 & .50 & .52 & .50 \\
Season (0=Spring, 1=Summer) & .32 & .47 & .08 & .27 \\
Black (Non-Hispanic Whites Omitted) & .14 & .35 & .12 & .33 \\
Hispanic & .03 & .18 & .05 & .22 \\
Other & .18 & .39 & .18 & .39 \\
North (South is Omitted Category) & .22 & .41 & .24 & .43 \\
Midwest & .21 & .41 & .23 & .42 \\
West & .19 & .39 & .20 & .40 \\
Rural (Urban is Omitted Category) & .14 & .34 & .15 & .35 \\
Unknown Residence & 2.24 & 1.03 & .73 & .74 \\
Income (Lowess prediction of \# probs) & & & & \\
\end{tabular}

Models Estimating 1999-4/2001 and 1999 - 12/2002 Trends

\begin{tabular}{|c|c|c|c|c|}
\hline & \multicolumn{2}{|c|}{ Mother-Only Families } & \multicolumn{2}{|c|}{ Two-Parent Families } \\
\hline & Mean & S.D. & Mean & S.D. \\
\hline \multicolumn{5}{|l|}{ Dependent Variables } \\
\hline Has One or More Problems? & .39 & .49 & .14 & .35 \\
\hline Food Insecure? (USDA Measure) & .28 & .45 & .09 & .29 \\
\hline Has Eight or More Problems? & .09 & .28 & .02 & .14 \\
\hline Number of Problems (0-18) & 2.01 & 3.32 & .61 & 1.90 \\
\hline \multicolumn{5}{|l|}{ Independent Variables } \\
\hline Black (Non-Hispanic Whites Omitted) & .32 & .47 & .08 & .27 \\
\hline Hispanic & .14 & .35 & .13 & .34 \\
\hline Other & .03 & .18 & .05 & .23 \\
\hline North (South is Omitted Category) & .18 & .39 & .18 & .39 \\
\hline Midwest & .22 & .41 & .24 & .43 \\
\hline West & .21 & .41 & .23 & .42 \\
\hline Rural (Urban is Omitted Category) & .18 & .38 & .19 & .39 \\
\hline Unknown Residence & .14 & .34 & .15 & .35 \\
\hline Income (Lowess prediction of \# probs) & 2.17 & 1.04 & .70 & .73 \\
\hline
\end{tabular}

Source: Food Security Supplement to the Current Population Survey, 1995-2002.

Sample sizes: 20,091 single mothers, 58,138 married mothers in top panel, 31,231 single mothers and 89,771 married mothers in bottom panel. Sample sizes are smaller for models that control income. See the notes for Table 2 for details about the dependent variables. Descriptive statistics for our household size dummies and year dummies are not shown. 
Table A.4: Prevalence of Selected Food-Related Problems among Mother-

Only and Two-Parent Families in FSS: 1995-2002

(standard errors in parentheses)

\begin{tabular}{|c|c|c|c|c|c|c|c|c|c|c|}
\hline & \multicolumn{4}{|c|}{ Survey years - spring } & \multicolumn{3}{|c|}{ Survey years - late summer } & \multirow{2}{*}{$\begin{array}{c}\text { December } \\
2001\end{array}$} & \multirow{2}{*}{$\begin{array}{c}\text { December } \\
2002\end{array}$} & \multirow{2}{*}{$\begin{array}{l}\text { Largest SE of } \\
\text { all btwn-year diff's }\end{array}$} \\
\hline & 1995 & 1997 & 1999 & 2001 & 1996 & 1998 & 2000 & & & \\
\hline \multicolumn{11}{|c|}{ Ran Short Of Money, Stretched Food } \\
\hline \multirow[t]{2}{*}{ Mother-Only } & 56.7 & 50.3 & 47.6 & 46.3 & 56.2 & 51.0 & 46.5 & 48.0 & 45.0 & \\
\hline & $(.9)$ & $(.8)$ & $(.9)$ & $(1.0)$ & $(.8)$ & $(.8)$ & (.9) & (.9) & $(.8)$ & $(1.3)$ \\
\hline \multirow[t]{2}{*}{ Two-Parent } & 34.6 & 29.0 & 27.5 & 27.0 & 32.8 & 28.9 & 26.7 & 26.4 & 24.1 & \\
\hline & $(.5)$ & $(.5)$ & $(.5)$ & $(.5)$ & $(.5)$ & $(.5)$ & $(.5)$ & $(.5)$ & $(.4)$ & $(.7)$ \\
\hline \multirow[t]{2}{*}{ Difference } & 22.0 & 21.3 & 20.1 & 19.3 & 23.5 & 22.1 & 19.8 & 21.5 & 20.9 & \\
\hline & $(1.0)$ & $(1.0)$ & $(1.0)$ & $(1.2)$ & $(1.0)$ & $(.9)$ & $(1.0)$ & $(1.0)$ & $(.9)$ & $(1.5)$ \\
\hline \multirow[t]{2}{*}{ Ratio } & 1.6 & 1.7 & 1.7 & 1.7 & 1.7 & 1.8 & 1.7 & 1.8 & 1.9 & \\
\hline & $(.03)$ & $(.04)$ & $(.04)$ & $(.05)$ & $(.04)$ & $(.04)$ & $(.04)$ & $(.05)$ & $(.05)$ & $(.1)$ \\
\hline \multicolumn{11}{|c|}{ Got/Borrowed Food From Others } \\
\hline \multirow[t]{2}{*}{ Mother-Only } & 23.7 & 21.8 & 17.6 & 17.5 & 24.0 & 21.6 & 18.1 & 19.0 & & \\
\hline & $(.7)$ & $(.7)$ & $(.7)$ & $(.8)$ & (.7) & (.7) & $(.7)$ & (.7) & & (1.1) \\
\hline \multirow[t]{2}{*}{ Two-Parent } & 6.8 & 5.5 & 4.6 & 4.8 & 7.0 & 5.7 & 4.7 & 5.3 & & \\
\hline & (.3) & $(.2)$ & $(.2)$ & (.3) & (.3) & $(.2)$ & $(.2)$ & $(.2)$ & & $(.4)$ \\
\hline \multirow[t]{2}{*}{ Difference } & 17.0 & 16.3 & 13.0 & 12.7 & 16.9 & 16.0 & 13.4 & 13.6 & & \\
\hline & $(.8)$ & $(.7)$ & (.7) & $(.8)$ & $(.8)$ & (.7) & (.7) & (.7) & & (1.1) \\
\hline \multirow[t]{2}{*}{ Ratio } & 3.5 & 4.0 & 3.8 & 3.6 & 3.4 & 3.8 & 3.9 & 3.6 & & \\
\hline & $(.2)$ & $(.2)$ & $(.2)$ & (.3) & $(.2)$ & $(.2)$ & $(.2)$ & $(.2)$ & & $(.3)$ \\
\hline \multicolumn{11}{|c|}{ Got Emergency Food From Food Pantry } \\
\hline \multirow[t]{2}{*}{ Mother-Only } & 9.0 & 6.9 & 7.1 & 8.0 & 8.7 & 8.1 & 7.6 & 8.2 & 8.3 & \\
\hline & $(.5)$ & $(.4)$ & $(.4)$ & $(.6)$ & $(.5)$ & $(.5)$ & $(.5)$ & $(.5)$ & $(.5)$ & $(.7)$ \\
\hline \multirow[t]{2}{*}{ Two-Parent } & 2.7 & 1.6 & 1.5 & 1.9 & 2.0 & 1.6 & 1.5 & 2.2 & 2.1 & \\
\hline & $(.2)$ & $(.1)$ & $(.1)$ & $(.2)$ & $(.1)$ & $(.1)$ & $(.1)$ & $(.2)$ & $(.2)$ & $(.2)$ \\
\hline \multirow[t]{2}{*}{ Difference } & 6.3 & 5.3 & 5.5 & 6.1 & 6.7 & 6.6 & 6.1 & 6.0 & 6.2 & \\
\hline & $(.5)$ & $(.4)$ & $(.5)$ & (.6) & $(.5)$ & $(.5)$ & (.5) & $(.5)$ & $(.5)$ & $(.8)$ \\
\hline \multirow[t]{2}{*}{ Ratio } & 3.3 & 4.4 & 4.6 & 4.2 & 4.4 & 5.2 & 5.0 & 3.7 & 3.9 & \\
\hline & (.3) & $(.4)$ & $(.5)$ & $(.5)$ & (.4) & $(.5)$ & $(.5)$ & $(.3)$ & (.3) & $(.7)$ \\
\hline
\end{tabular}




\begin{tabular}{|c|c|c|c|c|c|c|c|c|c|c|}
\hline & \multicolumn{4}{|c|}{ Survey years - spring } & \multicolumn{3}{|c|}{ Survey years - late summer } & \multirow{2}{*}{$\begin{array}{c}\text { December } \\
2001 \\
\end{array}$} & \multirow{2}{*}{$\begin{array}{c}\text { December } \\
2002 \\
\end{array}$} & \multirow{2}{*}{$\begin{array}{c}\text { Largest SE of } \\
\text { all btwn-year diff's }\end{array}$} \\
\hline & 1995 & 1997 & 1999 & 2001 & 1996 & 1998 & 2000 & & & \\
\hline \multicolumn{11}{|c|}{ Average Number of Problems (0-18) } \\
\hline \multirow[t]{2}{*}{ Mother-Only } & 2.3 & 1.9 & 1.8 & 1.8 & 2.3 & 2.1 & 1.9 & 1.9 & 1.9 & \\
\hline & $(.1)$ & $(.1)$ & $(.1)$ & $(.1)$ & $(.1)$ & $(.1)$ & $(.1)$ & $(.1)$ & $(.1)$ & $(.1)$ \\
\hline \multirow[t]{2}{*}{ Two-Parent } & 0.7 & 0.5 & 0.5 & 0.6 & 0.7 & 0.6 & 0.6 & 0.6 & 0.6 & \\
\hline & $(.02)$ & $(.02)$ & $(.02)$ & $(.02)$ & $(.02)$ & $(.02)$ & $(.02)$ & $(.02)$ & $(.02)$ & $(.03)$ \\
\hline \multirow[t]{2}{*}{ Difference } & 1.6 & 1.4 & 1.3 & 1.2 & 1.5 & 1.5 & 1.3 & 1.3 & 1.4 & \\
\hline & $(.1)$ & $(.1)$ & $(.1)$ & $(.1)$ & $(.1)$ & $(.1)$ & $(.1)$ & $(.1)$ & $(.1)$ & $(.1)$ \\
\hline \multirow[t]{2}{*}{ Ratio } & 3.4 & 3.6 & 3.4 & 2.9 & 3.2 & 3.4 & 3.2 & 3.2 & 3.3 & \\
\hline & $(.1)$ & $(.2)$ & $(.2)$ & $(.2)$ & $(.1)$ & $(.2)$ & $(.2)$ & $(.1)$ & $(.1)$ & $(.3)$ \\
\hline \multicolumn{11}{|c|}{ Food Insecure - USDA } \\
\hline \multirow[t]{2}{*}{ Mother-Only } & 30.6 & 26.9 & 26.8 & 25.9 & 30.6 & 30.3 & 27.3 & 27.4 & 27.9 & \\
\hline & $(.8)$ & $(1.0)$ & (.9) & (.9) & $(.8)$ & $(.9)$ & $(.9)$ & $(.8)$ & (.7) & (1.4) \\
\hline \multirow[t]{2}{*}{ Two-Parent } & 9.9 & 7.7 & 8.2 & 9.3 & 10.2 & 9.5 & 9.2 & 9.0 & 8.9 & \\
\hline & (.3) & (.4) & $(.3)$ & (.4) & $(.3)$ & $(.3)$ & $(.3)$ & $(.3)$ & $(.3)$ & $(.5)$ \\
\hline \multirow[t]{2}{*}{ Difference } & 20.7 & 19.2 & 18.7 & 16.6 & 20.4 & 20.8 & 18.2 & 18.4 & 19.0 & \\
\hline & (.9) & $(1.1)$ & (.9) & $(1.0)$ & $(.8)$ & $(.9)$ & $(.9)$ & $(.8)$ & $(.8)$ & $(1.4)$ \\
\hline \multirow[t]{2}{*}{ Ratio } & 3.1 & 3.5 & 3.3 & 2.8 & 3.0 & 3.2 & 3.0 & 3.0 & 3.1 & \\
\hline & $(.1)$ & $(.2)$ & $(.2)$ & $(.1)$ & $(.1)$ & $(.1)$ & $(.1)$ & $(.1)$ & $(.1)$ & $(.3)$ \\
\hline \multicolumn{11}{|c|}{ Worried Food Would Run Out } \\
\hline \multirow[t]{2}{*}{ Mother-Only } & 38.7 & 34.4 & 33.1 & 31.5 & 38.1 & 36.6 & 32.8 & 33.7 & 34.5 & \\
\hline & $(.8)$ & $(.8)$ & $(.8)$ & $(1.0)$ & $(.8)$ & $(.8)$ & $(.9)$ & $(.8)$ & $(.8)$ & (1.3) \\
\hline \multirow[t]{2}{*}{ Two-Parent } & 12.9 & 10.7 & 10.9 & 11.8 & 13.2 & 12.5 & 11.5 & 11.7 & 11.7 & \\
\hline & (.4) & (.3) & (.3) & (.4) & $(.4)$ & $(.3)$ & $(.4)$ & $(.3)$ & (.3) & (.6) \\
\hline \multirow[t]{2}{*}{ Difference } & 25.8 & 23.7 & 22.2 & 19.7 & 24.9 & 24.1 & 21.3 & 22.1 & 22.7 & \\
\hline & (.9) & (.9) & (.9) & $(1.0)$ & $(.9)$ & $(.9)$ & $(1.0)$ & $(.9)$ & (.9) & (1.4) \\
\hline \multirow[t]{2}{*}{ Ratio } & 3.0 & 3.2 & 3.0 & 2.7 & 2.9 & 2.9 & 2.8 & 2.9 & 2.9 & \\
\hline & (.1) & (.1) & (.1) & (.1) & (.1) & $(.1)$ & (.1) & $(.1)$ & (.1) & $(.2)$ \\
\hline
\end{tabular}




\begin{tabular}{|c|c|c|c|c|c|c|c|c|c|c|}
\hline & \multicolumn{4}{|c|}{ Survey years - spring } & \multicolumn{3}{|c|}{ Survey years - late summer } & \multirow{2}{*}{$\begin{array}{c}\text { December } \\
2001\end{array}$} & \multirow{2}{*}{$\begin{array}{l}\text { December } \\
2002\end{array}$} & \multirow{2}{*}{$\begin{array}{c}\text { Largest SE of } \\
\text { all btwn-year diff's }\end{array}$} \\
\hline & 1995 & 1997 & 1999 & 2001 & 1996 & 1998 & 2000 & & & \\
\hline \multicolumn{11}{|c|}{ Adult Cut Size of Or Skipped Meal } \\
\hline \multirow[t]{2}{*}{ Mother-Only } & 17.7 & 14.4 & 12.3 & 12.5 & 17.6 & 16.3 & 12.5 & 14.0 & 13.8 & \\
\hline & $(.7)$ & $(.6)$ & $(.6)$ & $(.7)$ & (.6) & $(.7)$ & (.6) & (.6) & (.6) & $(1.0)$ \\
\hline \multirow[t]{2}{*}{ Two-Parent } & 5.1 & 3.9 & 3.6 & 3.9 & 5.5 & 4.4 & 4.3 & 4.0 & 4.0 & \\
\hline & $(.2)$ & $(.2)$ & $(.2)$ & $(.2)$ & $(.2)$ & $(.2)$ & $(.2)$ & $(.2)$ & $(.2)$ & $(.3)$ \\
\hline \multirow[t]{2}{*}{ Difference } & 12.6 & 10.5 & 8.7 & 8.6 & 12.1 & 11.9 & 8.2 & 10.0 & 9.8 & \\
\hline & $(.7)$ & $(.6)$ & $(.7)$ & $(.7)$ & $(.7)$ & $(.7)$ & (.6) & (.6) & (.6) & $(1.0)$ \\
\hline \multirow[t]{2}{*}{ Ratio } & 3.4 & 3.7 & 3.4 & 3.2 & 3.2 & 3.7 & 2.9 & 3.5 & 3.5 & \\
\hline & $(.2)$ & $(.2)$ & $(.3)$ & $(.3)$ & $(.2)$ & $(.3)$ & $(.2)$ & $(.2)$ & $(.2)$ & $(.4)$ \\
\hline \multicolumn{11}{|c|}{ Respondent Lost Weight Due to Poverty } \\
\hline \multirow[t]{2}{*}{ Mother-Only } & 4.5 & 3.7 & 2.7 & 3.6 & 4.9 & 3.7 & 3.9 & 3.1 & 3.7 & \\
\hline & (.4) & $(.3)$ & (.3) & $(.4)$ & $(.4)$ & $(.3)$ & (.3) & $(.3)$ & (.3) & $(.5)$ \\
\hline \multirow[t]{2}{*}{ Two-Parent } & 1.0 & 0.8 & 0.6 & 1.0 & 1.2 & 0.7 & 0.7 & 0.7 & 0.7 & \\
\hline & $(.1)$ & $(.1)$ & (.1) & (.1) & (.1) & (.1) & (.1) & (.1) & (.1) & $(.2)$ \\
\hline \multirow[t]{2}{*}{ Difference } & 3.4 & 2.9 & 2.1 & 2.6 & 3.6 & 3.0 & 3.2 & 2.4 & 3.0 & \\
\hline & (.4) & $(.3)$ & (.3) & $(.4)$ & (.4) & (.3) & (.3) & (.3) & (.3) & $(.6)$ \\
\hline \multirow[t]{2}{*}{ Ratio } & 4.3 & 4.8 & 4.9 & 3.7 & 3.9 & 5.4 & 5.7 & 4.5 & 5.1 & \\
\hline & (.6) & $(.7)$ & (.9) & (.6) & $(.5)$ & $(.8)$ & (.9) & (.7) & (.8) & $(1.2)$ \\
\hline \multicolumn{11}{|c|}{ Child Not Eating Enough } \\
\hline \multirow[t]{2}{*}{ Mother-Only } & 10.6 & 7.8 & 9.0 & 7.8 & 9.9 & 9.4 & 8.8 & 7.9 & 8.1 & \\
\hline & $(.5)$ & $(.5)$ & (.6) & (.6) & $(.5)$ & $(.5)$ & $(.5)$ & $(.5)$ & $(.5)$ & $(.8)$ \\
\hline \multirow[t]{2}{*}{ Two-Parent } & 2.7 & 2.1 & 2.3 & 2.9 & 2.8 & 2.6 & 2.5 & 2.3 & 2.2 & \\
\hline & $(.2)$ & $(.2)$ & $(.2)$ & $(.2)$ & $(.2)$ & $(.2)$ & $(.2)$ & $(.2)$ & $(.2)$ & $(.3)$ \\
\hline \multirow[t]{2}{*}{ Difference } & 7.9 & 5.7 & 6.7 & 4.9 & 7.2 & 6.8 & 6.3 & 5.6 & 6.0 & \\
\hline & (.6) & $(.5)$ & (.6) & (.6) & $(.5)$ & (.6) & $(.5)$ & $(.5)$ & $(.5)$ & $(.8)$ \\
\hline \multirow[t]{2}{*}{ Ratio } & 3.9 & 3.6 & 3.9 & 2.7 & 3.6 & 3.6 & 3.5 & 3.5 & 3.7 & \\
\hline & $(.3)$ & $(.3)$ & $(.4)$ & (.3) & (.3) & (.3) & (.3) & (.3) & $(.3)$ & $(.5)$ \\
\hline
\end{tabular}




\begin{tabular}{|c|c|c|c|c|c|c|c|c|c|c|}
\hline & \multicolumn{4}{|c|}{ Survey years - spring } & \multicolumn{3}{|c|}{ Survey years - late summer } & \multirow{2}{*}{$\begin{array}{c}\text { December } \\
2001 \\
\end{array}$} & \multirow{2}{*}{\begin{tabular}{|c|} 
December \\
2002 \\
\end{tabular}} & \multirow{2}{*}{$\begin{array}{c}\text { Largest SE of } \\
\text { all btwn-year diff's }\end{array}$} \\
\hline & 1995 & 1997 & 1999 & 2001 & 1996 & 1998 & 2000 & & & \\
\hline \multicolumn{11}{|c|}{ Child Went Hungry for Day } \\
\hline \multirow[t]{2}{*}{ Mother-Only } & 4.0 & 2.4 & 1.8 & 1.9 & 3.1 & 2.6 & 1.9 & 1.6 & 2.1 & \\
\hline & (.3) & $(.3)$ & $(.3)$ & $(.3)$ & $(.3)$ & (.3) & $(.2)$ & $(.2)$ & $(.2)$ & $(.5)$ \\
\hline \multirow[t]{2}{*}{ Two-Parent } & 0.9 & 0.5 & 0.4 & 0.7 & 0.7 & 0.6 & 0.3 & 0.4 & 0.4 & \\
\hline & $(.1)$ & $(.1)$ & $(.1)$ & $(.1)$ & $(.1)$ & $(.1)$ & $(.1)$ & $(.1)$ & $(.1)$ & $(.1)$ \\
\hline \multirow[t]{2}{*}{ Difference } & 3.1 & 1.9 & 1.3 & 1.2 & 2.5 & 2.1 & 1.6 & 1.2 & 1.7 & \\
\hline & (.4) & (.4) & (.3) & (.3) & (.3) & (.3) & $(.2)$ & (.2) & (.2) & (.5) \\
\hline \multirow[t]{2}{*}{ Ratio } & 4.6 & 4.9 & 4.1 & 2.8 & 4.7 & 4.7 & 6.4 & 4.3 & 5.6 & \\
\hline & (.7) & (1.2) & (1.0) & (.6) & (.7) & (.9) & (1.5) & (1.0) & (1.1) & (1.9) \\
\hline
\end{tabular}

Source: Food Security Supplement to the Current Population Survey, 1995-2002.

Unweighted sample sizes range from 2,738 to 4,371 for mother-only families and 8,300 to 11,907 for two-parent families. The "Difference" line is the prevalence rate for motheronly families minus that for two-parent families. The ratio is the mother-only prevalence rate divided by the two-parent rate. Mother-only families improve relative to married mothers when the difference or ratio declines. Standard errors account for the CPS complex survey design (see the appendix). 
Table A.5: Supplementary FSS Employment and Income Statistics: 1995-2001

(standard errors in parentheses)

\begin{tabular}{|c|c|c|c|c|c|c|c|c|c|}
\hline & \multicolumn{4}{|c|}{ Survey years - spring } & \multicolumn{3}{|c|}{ Survey years - late summer } & \multirow{2}{*}{$\begin{array}{c}\text { December } \\
2001 \\
\end{array}$} & \multirow{2}{*}{$\begin{array}{c}\text { Largest SE of } \\
\text { all btwn-year diff's }\end{array}$} \\
\hline & 1995 & 1997 & 1999 & 2001 & 1996 & 1998 & 2000 & & \\
\hline \multicolumn{10}{|c|}{ Percent Employed } \\
\hline \multirow[t]{2}{*}{ Mother-Only } & 60.7 & 67.0 & 71.5 & 74.0 & 64.7 & 70.3 & 73.3 & 72.2 & \\
\hline & $(.8)$ & $(.9)$ & $(.9)$ & $(.9)$ & $(.8)$ & $(.8)$ & $(.8)$ & $(.8)$ & $(1.3)$ \\
\hline \multirow[t]{2}{*}{ Two-Parent } & 67.0 & 68.3 & 68.3 & 67.0 & 68.5 & 66.6 & 67.7 & 67.4 & \\
\hline & $(.5)$ & (.6) & $(.5)$ & (.6) & $(.5)$ & $(.5)$ & $(.5)$ & $(.5)$ & $(.8)$ \\
\hline \multicolumn{10}{|c|}{ Percent Employed - Mothers without a High School Diploma } \\
\hline \multirow[t]{2}{*}{ Mother-Only } & 35.8 & 39.3 & 45.1 & 50.0 & 39.4 & 44.5 & 53.5 & 52.0 & \\
\hline & $(1.6)$ & $(2.0)$ & $(2.1)$ & $(2.3)$ & $(1.7)$ & $(2.0)$ & $(1.9)$ & (1.9) & $(3.1)$ \\
\hline \multirow[t]{2}{*}{ Two-Parent } & 41.0 & 44.7 & 42.7 & 43.0 & 45.1 & 44.2 & 48.2 & 45.8 & \\
\hline & $(1.5)$ & $(1.8)$ & $(1.8)$ & $(1.9)$ & $(1.5)$ & (1.7) & (1.6) & (1.6) & $(2.6)$ \\
\hline \multicolumn{10}{|c|}{ Mean Family Income } \\
\hline \multirow[t]{2}{*}{ Mother-Only } & 24,161 & 26,192 & 28,773 & 31,605 & 24,899 & 27,514 & 30,958 & 31,101 & \\
\hline & $(404)$ & $(523)$ & $(548)$ & $(597)$ & $(426)$ & $(485)$ & $(505)$ & $(505)$ & (811) \\
\hline \multirow[t]{2}{*}{ Two-Parent } & 59,468 & 61,974 & 65,679 & 66,988 & 59,943 & 64,778 & 66,104 & 67,317 & \\
\hline & $(410)$ & $(476)$ & $(466)$ & $(478)$ & $(409)$ & $(462)$ & $(421)$ & $(420)$ & $(674)$ \\
\hline \multicolumn{10}{|c|}{ Mean Family Income - Mothers without a High School Diploma } \\
\hline \multirow[t]{2}{*}{ Mother-Only } & 14,229 & 15,400 & 16,395 & 18,703 & 15,245 & 15,999 & 18,702 & 18,880 & \\
\hline & $(570)$ & $(733)$ & $(782)$ & $(946)$ & $(616)$ & $(645)$ & $(761)$ & $(790)$ & $(1,233)$ \\
\hline \multirow[t]{2}{*}{ Two-Parent } & 27,920 & 28,300 & 32,375 & 33,244 & 28,040 & 30,276 & 32,628 & 34,040 & \\
\hline & $(662)$ & $(784)$ & $(892)$ & $(964)$ & $(724)$ & $(842)$ & $(838)$ & $(890)$ & $(1,314)$ \\
\hline \multicolumn{10}{|c|}{ Mean Family Income - Working Mothers } \\
\hline \multirow[t]{2}{*}{ Mother-Only } & 29,972 & 31,384 & 33,525 & 34,842 & 29,612 & 31,593 & 34,594 & 35,179 & \\
\hline & $(541)$ & $(671)$ & $(670)$ & $(687)$ & $(551)$ & $(597)$ & $(601)$ & $(600)$ & $(960)$ \\
\hline \multirow[t]{2}{*}{ Two-Parent } & 64,330 & 66,658 & 69,934 & 71,273 & 64,762 & 68,683 & 70,180 & 71,301 & \\
\hline & $(483)$ & $(559)$ & $(544)$ & $(558)$ & $(483)$ & $(549)$ & $(495)$ & $(491)$ & (789) \\
\hline \multicolumn{10}{|c|}{ Mean Family Income - Non-working Mothers } \\
\hline \multirow[t]{2}{*}{ Mother-Only } & 15,423 & 15,836 & 16,598 & 22,438 & 16,519 & 17,959 & 20,794 & 20,282 & \\
\hline & (519) & (683) & $(753)$ & (1118) & $(585)$ & $(717)$ & $(826)$ & $(815)$ & $(1,390)$ \\
\hline \multirow[t]{2}{*}{ Two-Parent } & 49,319 & 51,792 & 56,438 & 58,242 & 49,422 & 56,754 & 57,468 & 59,056 & \\
\hline & $(724)$ & (854) & $(852)$ & $(867)$ & $(722)$ & $(825)$ & $(760)$ & (774) & $(1,217)$ \\
\hline
\end{tabular}

Source: 1995-2001 Food Security Supplement to the CPS. Family income referst 5 the household head's family. The measure is derived by taking

the midpoint of a respondent's income category and inflating it to constant 2001 dollars using the CPI-U-RS. Standard errors account for the complex 